ARTICLE

https://doi.org/10.1038/s41467-019-12890-3

\title{
Carbon and health implications of trade restrictions
}

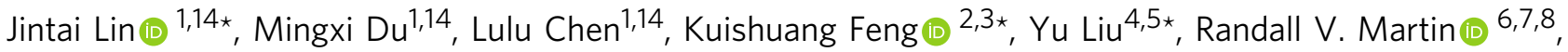 \\ Jingxu Wang ${ }^{1}$, Ruijing Ni ${ }^{1}$, Yu Zhao ${ }^{9}$, Hao Kong${ }^{1}$, Hongjian Weng ${ }^{1}$, Mengyao Liu', Aaron van Donkelaar ${ }^{6,7}$, \\ Qiuyu Liu ${ }^{10}$ \& Klaus Hubacek (1D 11,12,13
}

In a globalized economy, production of goods can be disrupted by trade disputes. Yet the resulting impacts on carbon dioxide emissions and ambient particulate matter $\left(\mathrm{PM}_{2.5}\right)$ related premature mortality are unclear. Here we show that in contrast to a free trade world, with the emission intensity in each sector unchanged, an extremely anti-trade scenario with current tariffs plus an additional $25 \%$ tariff on each traded product would reduce the global export volume by $32.5 \%$, gross domestic product by $9.0 \%$, carbon dioxide by $6.3 \%$, and $\mathrm{PM}_{2.5^{-}}$ related mortality by $4.1 \%$. The respective impacts would be substantial for the United States, Western Europe and China. A freer trade scenario would increase global carbon dioxide emission and air pollution due to higher levels of production, especially in developing regions with relatively high emission intensities. Global collaborative actions to reduce emission intensities in developing regions could help achieve an economic-environmental win-win state through globalization.

\footnotetext{
${ }^{1}$ Laboratory for Climate and Ocean-Atmosphere Studies, Department of Atmospheric and Oceanic Sciences, School of Physics, Peking University, Beijing 100871, China. ${ }^{2}$ Institute of Blue and Green Development, Shandong University, Weihai 264209, China. ${ }^{3}$ Department of Geographical Sciences, University of Maryland, College Park, MD 20742, USA. ${ }^{4}$ Institutes of Science and Development, Chinese Academy of Sciences, Beijing 100190 , China. ${ }^{5}$ School of Public Policy and Management, University of Chinese Academy of Sciences, Beijing 100049, China. ${ }^{6}$ Department of Energy, Environmental \& Chemical Engineering, Washington University in St. Louis, St. Louis, Missouri, United States. ${ }^{7}$ Department of Physics and Atmospheric Science, Dalhousie University, Halifax, NS B3H 4R2, Canada. ${ }^{8}$ Smithsonian Astrophysical Observatory, Harvard-Smithsonian Center for Astrophysics, Cambridge, MA 02138, USA. ${ }^{9}$ School of the Environment, Nanjing University, 163 Xianlin Ave, Nanjing 210046, China. ${ }^{10}$ Department of Biological Sciences, University of Quebec at Montreal, Montreal H3C 3P8, Canada. ${ }^{11}$ Energy and Sustainability Research Institute Groningen (ESRIG), University of Groningen, Nijenborg 6, 9747 AG Groningen, The Netherlands. ${ }^{12}$ International Institute for Applied Systems Analysis, Schlossplatz 1, A-2361 Laxenburg, Austria. ${ }^{13}$ Department of Environmental Studies, Masaryk University, Jostova 10, 60200 Brno, Czech Republic. ${ }^{14}$ These authors contributed equally: Jintai Lin, Mingxi Du, Lulu Chen. *email: linjt@pku.edu.cn; kfeng@umd.edu; liuyu@casipm.ac.cn
} 
E conomies worldwide are tightly connected through trade. Goods and services are consumed and produced in different parts of the world often with different resource availability, economic and energy structures, environmental regulations, and meteorological and chemical conditions ${ }^{1}$. Recent work based on empirical trade data has shown that, with given amounts of global total burdens, large quantities of carbon dioxide $\left(\mathrm{CO}_{2}\right)$, particulate matter $\left(\mathrm{PM}_{2.5}\right)$ pollution, and related premature deaths are embedded in traded products ${ }^{2-6}$; in other words, these environmental burdens are associated with production for export. However, whether trade improves or worsens environmental quality depends on the level of progress in the economy, regulation, and technological development ${ }^{7-9}$, which varies along global supply chains. In part as a reaction to perceived disadvantages caused by trade of certain goods and services, the past years have seen a number of attempts to restrict trade activities $^{10-13}$. Yet, the grand question of whether trade liberalization or restriction leads to a better global environment remains unclear.

Here, we assess the potential impacts of trade restrictions on $\mathrm{CO}_{2}$ emissions and $\mathrm{PM}_{2.5}$-related premature mortality at both global and regional scales. The assessment is done based on both economic and emission data in 2014, the latest year for which all necessary data are available. Based on five trade scenarios differentiated by the extent of trade restrictions, we take an interdisciplinary approach to integrating the latest standard Global Trade Analysis Project (GTAP, version 10 data base for 2014), a computable general equilibrium (CGE) model $^{14-16}$ for global trade and economic analysis, a customized emission inventory derived from the Community Emission Database System (CEDS) ${ }^{17}$ and Xia et al. ${ }^{18}$, the GEOS-Chem atmospheric chemical transport model $^{19}$, a satellite-based dataset for nearsurface $\mathrm{PM}_{2.5}$ mass concentrations ${ }^{20}$, and the Global Exposure Mortality Model (GEMM) ${ }^{21}$ for pollution exposure (see Methods for details). Emissions and premature deaths analyzed here are only those which are linked to changes in economic output of 20 industrial sectors and 13 aggregated regions associated with each trade scenario. Scenario-dependent $\mathrm{PM}_{2.5}$ considered here include secondary inorganic aerosols (SIOA, including sulfate, nitrate, and ammonium), black carbon (BC), and POA. We find substantial impacts of trade restrictions on the global magnitude and regional distribution of emissions and health burdens.

\section{Results and Discussion}

Global free trade (GFT) scenario. This scenario assumes zero border tax for all traded products. It leads to the highest global export volume, GDP, $\mathrm{CO}_{2}$ emissions, and premature deaths (Fig. 1a-d). As simulated by the CGE model ${ }^{16}$, the global export volume reaches 22.1 trillion and GDP reaches $\$ 79.3$ trillion in US Dollar in 2014. Western Europe, the US and China contribute, respectively $33.7 \%, 8.7 \%$, and $15.0 \%$ of the global export volume and $24.4 \%, 22.1 \%$, and $14.4 \%$ of global GDP (Fig. 1a, b). Global $\mathrm{CO}_{2}$ emission amounts to 25.6 Petagram $(\mathrm{Pg})$, of which $57.8 \%$ are contributed by China (29.6\%), the US (16.4\%), and Western Europe (11.8\%) (Fig. 1c). Note that global emissions do not include scenario-independent sources, which together are about 9.9 Pg (see Methods for details).

The regional distribution of pollutant emissions reveals a different picture (Supplementary Fig. 1). China, South Asia, and Middle East and North Africa are the top three emitters, and they together contribute $47.5-60.2 \%$ of the global emissions of sulfur dioxide, nitrogen oxides, ammonia, carbon monoxide, $\mathrm{BC}$, and POA. A major driver of the large amount of emissions in these regions is their high-emission intensities (i.e., emissions per monetary output). Supplementary Fig. 2 shows that emission intensities in these regions are about 7-23 times of those in Western Europe and the USA (pollutant dependent). In general, emission intensities in developing regions are much larger than those in developed regions, and regions with higher per capita GDP tend to have lower emission intensities (Supplementary Fig. 2).

High emissions in many developing regions contribute to their heavy $\mathrm{PM}_{2.5}$ pollution (Supplementary Fig. 3), in addition to the influences of meteorological and chemical conditions, as simulated by GEOS-Chem ${ }^{19}$. China and South Asia experience the highest anthropogenic, population-weighted $\mathrm{PM}_{2.5}$ concentrations $\left(22.6-23.9 \mu \mathrm{g} / \mathrm{m}^{3}\right.$, for scenario-dependent SIOA, BC, and POA together). For China and South Asia, their atmospheric conditions are also favorable for local pollution accumulation, i.e., the chemical efficiency of their emissions to form and accumulate $\mathrm{PM}_{2.5}$ locally are high (Supplementary Fig. 4). By comparison, favorable atmospheric conditions for South-East Asia and Pacific allow their pollution to be more quickly deposited to the ground or transported out of their territories, contributing to their relatively low $\mathrm{PM}_{2.5}$ concentrations. Nonetheless, atmospheric transport allows regionally emitted/formed pollution to be transferred to vast downwind areas (Supplementary Fig. 4).

In Scenario GFT, anthropogenic $\mathrm{PM}_{2.5}$ pollution (SIOA, BC, and POA together) leads to a large number of premature deaths worldwide (Fig. 1d, Supplementary Fig. 3). Based on the GEMM NCD+LRI pollution-health response model ${ }^{21}$, the number of deaths reaches 2.94 million [95\% CI: 1.72-4.14] globally, 1.02 million [95\% CI: $0.61-1.43$ ] in China, 0.89 million [95\% CI: 0.49-1.29] in South Asia, 0.29 million [95\% CI: 0.17-0.41] in Western Europe, and 0.11 million [95\% CI: 0.07-0.15] in the USA. The high values in China and South Asia are also due to their large baseline mortality ( 8.5 and 6.8 million, respectively).

Actual trade restriction scenario (ATR). This scenario represents the actual tariff situation in 2014. Compared to GFT, it has a global average border tax of about 5\% (see Supplementary Data 1 for regional details). This leads to reductions by about $5.4 \%$ in the global export volume ( $\$ 1.19$ trillion), 1.3\% in GDP (\$1.05 trillion), $1.2 \%$ in emissions (317.5 $\mathrm{Tg}$ for $\mathrm{CO}_{2}$ ), and $1.1 \%$ in $\mathrm{PM}_{2.5^{-}}$ related premature mortality (32.7 thousand) (Fig. 1e-h). The most affected region is Japan and Korea, whose export volume is reduced by $9.7 \%$, GDP by $3.1 \%, \mathrm{CO}_{2}$ emission by $3.7 \%$, and premature mortality by $2.1 \%$. This is because of the region's large dependence on trade. The impacts for China and South Asia are larger than the global average: by $10.7-17.4 \%$ for the export volume, $2.1-2.6 \%$ for GDP, $1.3-2.0 \%$ for $\mathrm{CO}_{2}$, and $1.0-1.3 \%$ for mortality. By comparison, the impacts on the US and Western Europe are smaller (by $1.2-4.0 \%$ for export volume, $0.7-0.9 \%$ for GDP, $0.75-0.84 \%$ for $\mathrm{CO}_{2}$, and $0.7-0.9 \%$ for mortality).

Sino-US trade war scenarios (TW1 and TW2). These two scenarios represent the increasing levels of bilateral trade wars between the US and China. Scenario TW1 represents the stage of the Sino-US trade war by the end of 2018 where, on top of ATR, the United States imposes additional border taxes for $\$ 250$ billion worth of products imported from China, while China imposes extra tariffs for $\$ 110$ billion worth of imported US products. Scenario TW2 represents a hypothetical full-blown stage of the Sino-US trade war where, on top of ATR, the two countries impose an additional $25 \%$ tariff on any product imported from the other country. As expected, the Sino-US trade war scenarios (TW1 and TW2) have lower amounts of carbon emissions and premature deaths than the GFT scenario for all regions (Fig. 1i-p). Compared to Scenario GFT, the global export volume is reduced by $5.8 \%$ in TW 1 and $6.1 \%$ in TW2, GDP by $1.46 \%$ and 


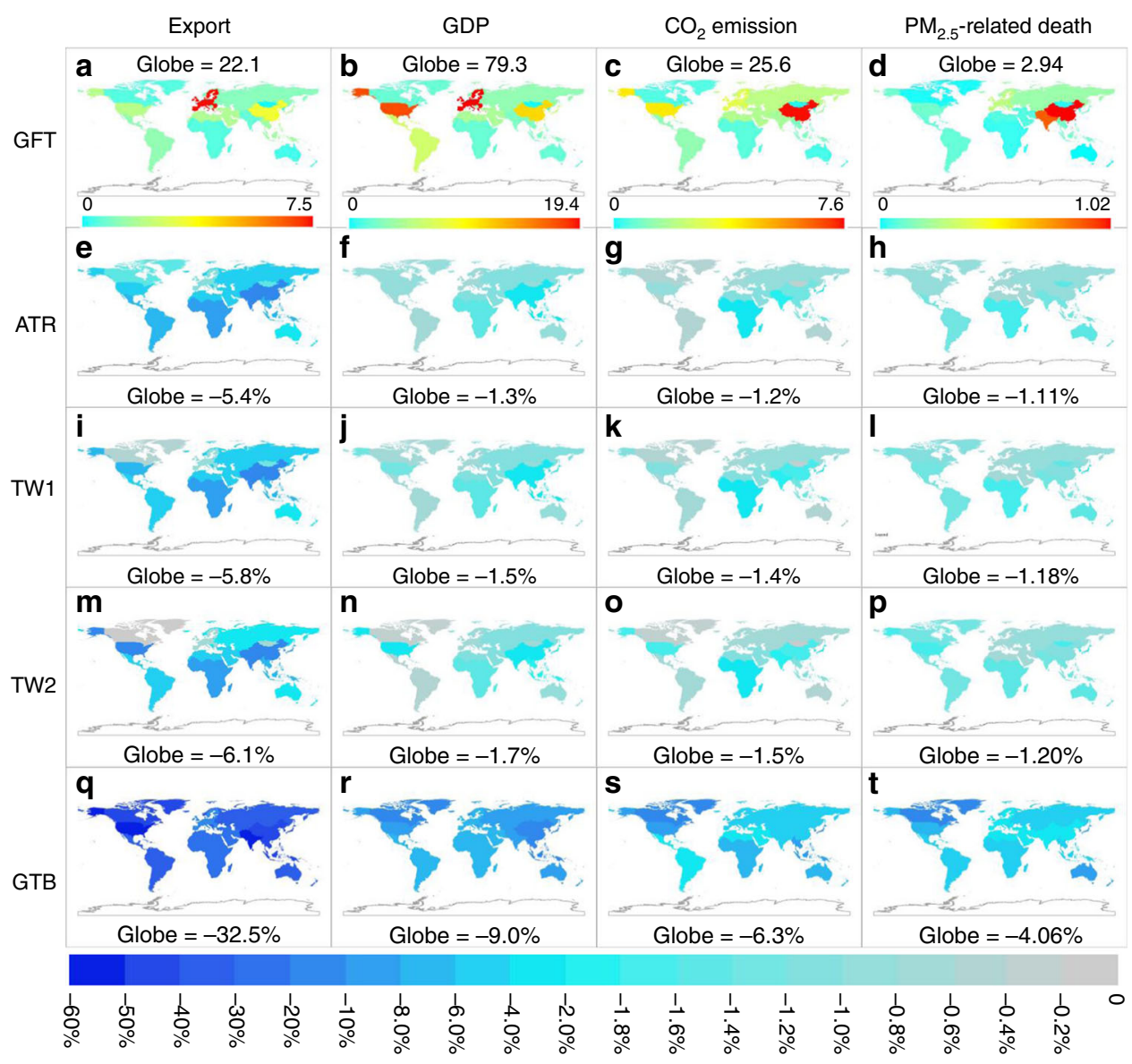

Fig. 1 Economic volume and environmental quality in each scenario. a-d Regional export volume (trillion \$), GDP (trillion \$), $\mathrm{CO}_{2}$ emission (Pg), and PM 2.5 related premature death (million) in Scenario GFT. e-t Relative changes from global free trade (GFT) scenario to each alternative scenario. Results here only include scenario-dependent sources. Note that the color scales are linear in (a-d) and nonlinear in (e-t)

$1.67 \%, \mathrm{CO}_{2}$ emission by $1.39 \%$ and $1.50 \%$, and premature mortality by $1.18 \%$ and $1.20 \%$, respectively.

Compared to ATR (Supplementary Fig. 5), the two trade war scenarios reduce GDP, $\mathrm{CO}_{2}$ emission, and mortality in both the USA (by $0.33-0.39 \%$ for TW1, $0.76-1.26 \%$ for TW2) and China (by $0.18-0.64 \%$ for TW1, $0.24-1.22 \%$ for TW2), but with increases in other regions. The most significant GDP increases are in the rest of North America, Japan and Korea, South-East Asia and rest of East Asia, because of their strong competitiveness in producing products targeted in the Sino-US trade war. Globally, the GDP, $\mathrm{CO}_{2}$ emission, and mortality are also reduced by $0.07-0.15 \%$ for TW 1 and $0.09-0.36 \%$ for TW 2 . The changes in global and regional GDP are consistent with other studies (Supplementary Table 1).

Global trade barrier (GTB) scenario. The GTB scenario represents a world in which every region has significant trade barriers. Compared to the GFT scenario, it leads to a substantial reduction by $32.5 \%$ in global export volume and $9.0 \%$ in GDP. The regional impacts are even more significant (Fig. 1q, r). Of the 13 aggregated regions, the US has the greatest reduction in export volume (57.2\%), and South-East Asia has the greatest reduction in GDP (16.0\%). The export volume of Western Europe, the US, South Asia, and China would decrease by $11.7-57.2 \%$ and GDP by $6.7-10.9 \%$.

When moving from the GFT scenario to the most restrictive GTB scenario, global emissions are reduced by $6.3 \%$ for $\mathrm{CO}_{2}$ and $4.7-6.3 \%$ for the six air pollutants. The regional impacts are broadly consistent with the impacts on GDP (Fig. 1s, t, Supplementary
Fig. 6), although there are substantial differences due to regional and sectoral disparities in emission intensity. For Western Europe, the US, and China, $\mathrm{CO}_{2}$ emissions are reduced by $4.9 \%, 8.2 \%$, and $5.4 \%$, respectively, and emissions of air pollutants are reduced by up to $3.3 \%, 8.4-10.0 \%$, and $2.6-4.7 \%$, respectively (Supplementary Fig. 6).

From GFT to GTB, $\mathrm{PM}_{2.5}$-related premature mortality decreases by 119 thousand (or $4.1 \%$ ). This value is larger than the number of total premature deaths in the US, rest of North America, and Oceania due to exposure to ambient $\mathrm{PM}_{2.5}$ in GFT. South Asia (35.5 thousand) and China (33.3 thousand) have the large absolute reductions in premature mortality. The rest of North America (10.3\%), Japan, and Korea (9.1\%), Oceania (9.0\%), and the USA (7.7\%) have the greatest relative reductions, that is, more than twice the global average reduction.

Synergy of all scenarios. Figure 2 presents the relative changes in regional $\mathrm{CO}_{2}$ emission and mortality as a function of GDP change across the individual scenarios relative to the GFT. In general, as the trade restrictions tighten from GFT to the actual trade in 2014 (ATR), to the Sino-US trade war scenarios (TW1 and TW2), and finally to the GTB scenario, regional GDP, $\mathrm{CO}_{2}$ emission, and mortality also decrease. However, there exist substantial regional differences in this relationship, as apparent from the scatter plot in Fig. 2. Overall, about $52-64 \%$ of global $\mathrm{CO}_{2}$ emission reduction and $78-83 \%$ of global mortality reduction from GFT to ATR, TW1, TW2, and GTB occur in developing regions (China, rest of East Asia, Economies in Transition, Latin America and Caribbean, Middle East and North Africa, South 

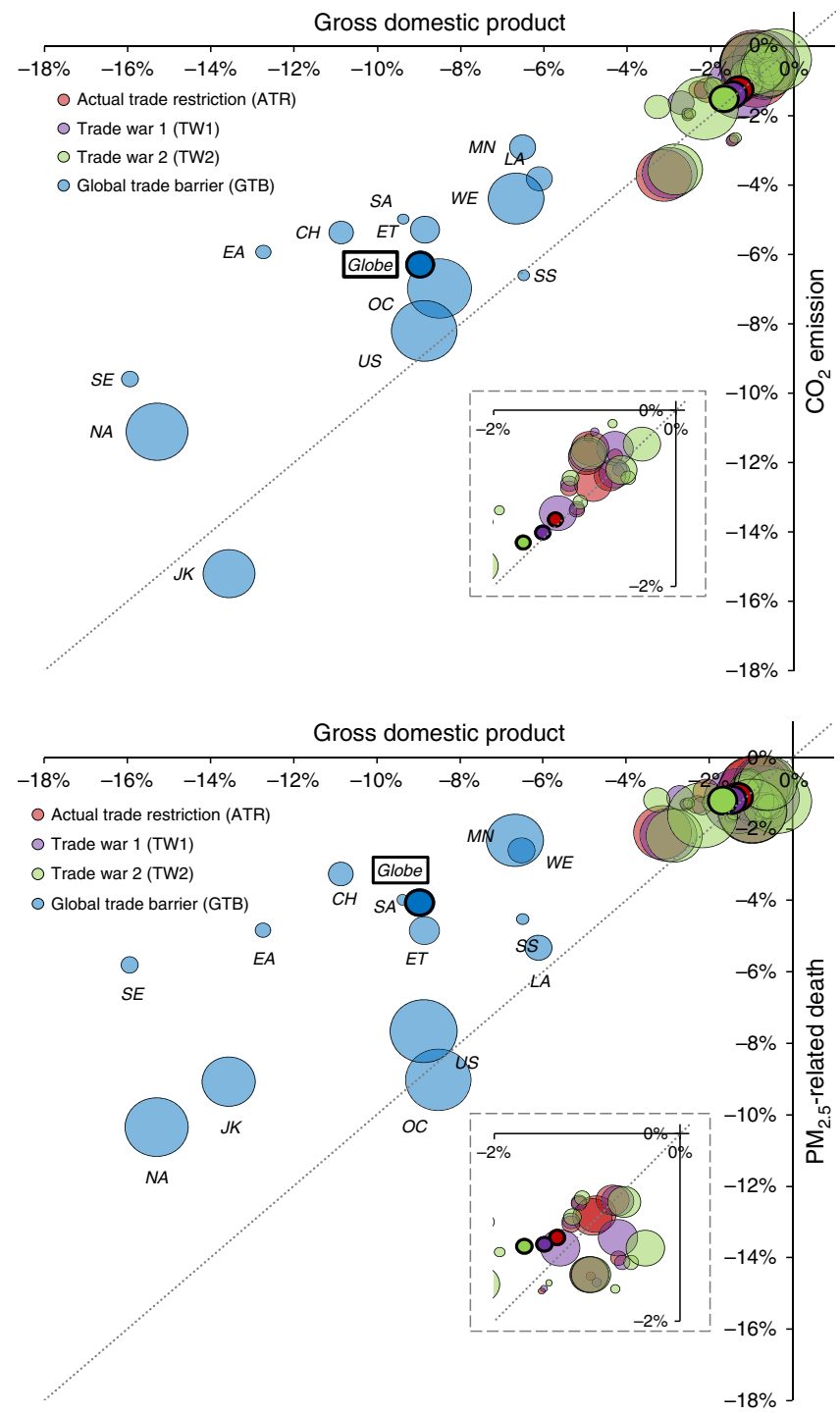

Fig. 2 Contrasting changes in economic performance and environmental quality. The Figures show the relative changes in regional $\mathrm{CO}_{2}$ emission and $\mathrm{PM}_{2.5}$ related premature mortality from global free trade scenario (GFT) to each alternative scenario, as a function of respective changes in regional GDP. The color of the dots denotes individual trade scenarios, and the size of the dots denotes the magnitude of regions' per capita GDP. The dots with darker colors and thicker borders denote the global values. The inserted Figures in dotted boxes are zoom-in ones to indicate ART, TW1, and TW2. Results here only include scenario-dependent sources. Regions include China (CH), rest of East Asia (EA), Economies in Transition (ET), Japan and Korea (JK), Latin America and Caribbean (LA), Middle East and North Africa (MN), rest of North America (NA), Oceania (OC), South Asia (SA), South-East Asia and Pacific (SE), Sub-Saharan Africa (SS), the United States (US), and Western Europe (WE)

Asia, South-East Asia and Pacific, and Sub-Saharan Africa), with the rest in developed regions (Fig. 3).

At the global level and for most regions, the relative reductions from GFT to GTB in terms of $\mathrm{CO}_{2}$ emissions and mortalities are less significant than the reduction in GDP. This means that restricting trade is not an effective approach for reducing emissions. This result also indicates enhanced (sectorally averaged) emission intensities of $\mathrm{CO}_{2}$ and pollutants in an antitrade world represented by Scenario GTB, compared to GFT. This is because individual economic sectors have different emission intensities $^{22,23}$ and different responses to economic shocks from trade restrictions. Sectors with high emission intensities such as Electricity and Road Transport are often not directly affected by trade restrictions, since they do not produce goods for trade. By comparison, sectors with low emission intensities, such as Wearing Apparel and Textiles are often directly affected by trade restrictions. As shown in Supplementary Fig. 7, the relative reduction in economic output from GFT to GTB is smaller in more emission-intensive sectors, resulting in increased relative contributions of emission-intensive sectors to global output.

For a given amount of relative reduction in GDP from GFT to GTB, developed regions tend to have greater relative reductions in mortality than developing regions do (Fig. 2). This is because in the more protected environments of developed regions, a given amount of pollution concentration change is more conducive to change in mortality risk ${ }^{21}$.

When moving from a GFT to a restricted trade scenario (GTB), the global export volume would decrease by $32.5 \%$. This means that there are still significant amounts of interregional trade activities in GTB. We do not simulate a situation in which all trade activities are banned, which would be highly unlikely to occur. Nonetheless, assuming a linear relationship between the change in global export volume and changes in $\mathrm{CO}_{2}$ emission and mortality, we estimate that fully banning trade would lead to reductions in global GDP, $\mathrm{CO}_{2}$ emission, and mortality by $27.0 \%$, $18.9 \%$, and $12.3 \%$, respectively, compared to a world with a larger extent of free trade.

Decoupling environmental impacts from trade liberalization. The above results imply that with fixed sectoral emission intensities, trade liberalization scenarios may lead to an improved global economy but at a larger environmental cost. These environmental side effects come with a higher amount of production, the influence of which is partially compensated by a reduction in sectorally averaged, global mean emission intensity due to changes in trade pattern and economic structure (Supplementary Fig. 7). Changes in $\mathrm{CO}_{2}$, pollutant emissions, and mortality are dominated by those in developing regions with higher emission intensities (Fig. 3). Thus, reducing emission intensities in developing regions is key to alleviating adverse environmental consequences of trade liberalization.

High emission intensities in developing regions are caused by multiple factors. Developing economies tend to rely on fossil fuel, especially coal, much more than developed economies, because of more limited access to cleaner or renewable energy sources which are usually more expensive and/or technologically challenging ${ }^{24,25}$. Meanwhile, developing economies are shifting toward producing emission-intensive goods whereas developed economies are shifting away 26,27. Developing regions also have looser environment regulations and enforcement and lower energy and product use efficiencies, due in part to lack of advanced technology and know-how ${ }^{28,29}$.

Global collaborative efforts can be made to reduce emission intensities in developing regions. This is of global value given the global climate impact of $\mathrm{CO}_{2}$ and the transboundary atmospheric transport of air pollutants ${ }^{3,6}$. The Paris Agreement has already included technological and financial support to developing regions ${ }^{30,31}$. Implementing and enhancing these aids would be valuable to alleviate the reliance of developing regions on fossil fuels, improve their energy and production efficiencies, and enhance their emission control capabilities. These actions might be accompanied by negotiations on moving toward more consistent environmental standards and policies (e.g., carbon pricing) across the globe ${ }^{32}$. 
a $\mathrm{SO}_{2}$

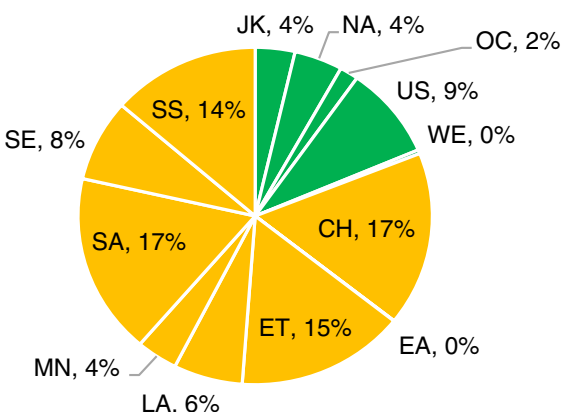

C $\mathrm{NO}_{x}$

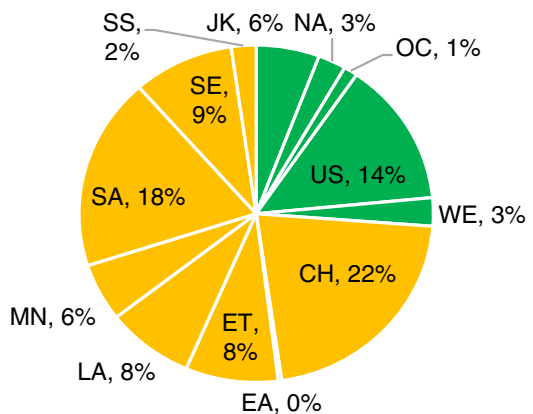

e $\mathrm{co}$

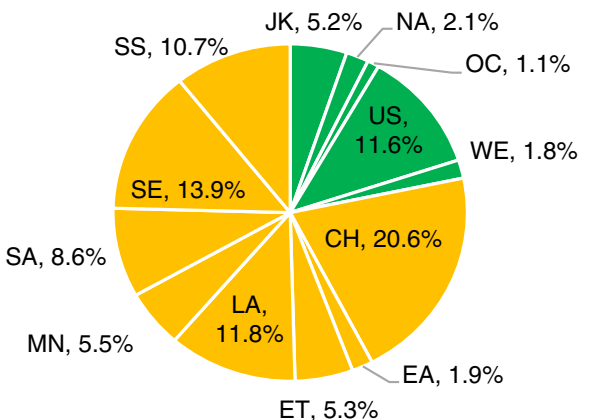

g $\mathrm{CO}_{2}$

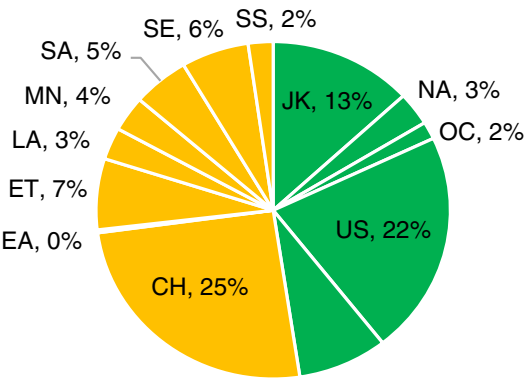

b OC

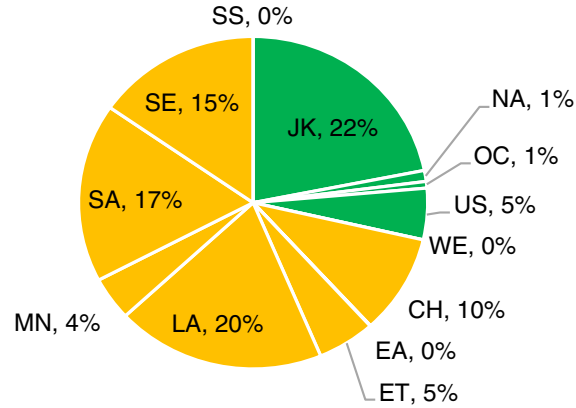

d $\mathrm{NH}_{3}$

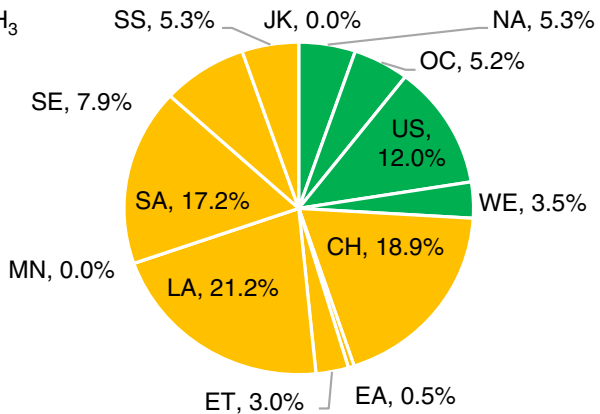

f $\mathrm{BC}$

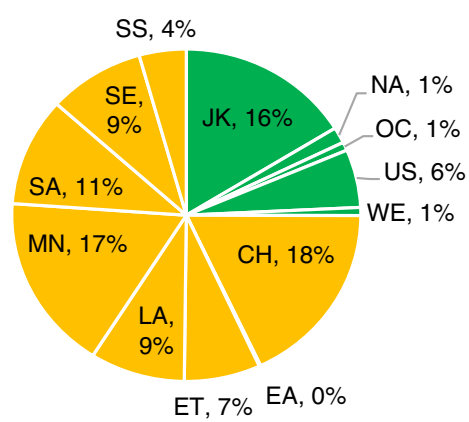

h Death

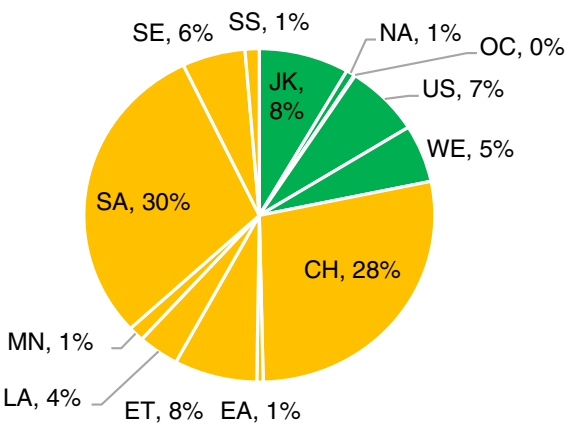

Fig. 3 Regional contributions to global changes in (a-f) pollutant emissions and (g) $\mathrm{CO}_{2}$ and $(\mathbf{h}) \mathrm{PM}_{2.5}$ related mortality from global free trade scenario (GFT) to global trade barrier (GTB) scenario. The green color represents developed regions, and the orange color represents developing regions. Results here only include scenario-dependent sources. Regions include China (CH), rest of East Asia (EA), Economies in Transition (ET), Japan and Korea (JK), Latin America and Caribbean (LA), Middle East and North Africa (MN), rest of North America (NA), Oceania (OC), South Asia (SA), South-East Asia and Pacific (SE), Sub-Saharan Africa (SS), the United States (US), and Western Europe (WE)

In order to estimate how trade liberalization can be accompanied by an improved global environment, we contrast GFT against an additional scenario (GFTT) which assumes global free trade plus sufficient global technological/financial support and more globally consistent environmental policies to further reduce emission intensities in developing regions. Enhancing environmental regulations in developing regions means an economic burden (at least in the beginning) to industries that may affect their competitiveness and subsequently alter interregional trade, which is not fully accounted for in GFTT. Nonetheless, enhancing the financial and technological support may reduce the initial shock to developing economies. Under the GFTT scenario, the emission intensity of a sector in any region that is higher than the global sectoral average is reduced to the average value. As a result, global $\mathrm{CO}_{2}$ emission would be reduced by $24.2 \%$, pollutant emissions by $27.3-53.6 \%$, and $\mathrm{PM}_{2.5}$-related premature deaths by $36.0 \%$. The respective regional reductions are substantial (Fig. 4). For example, $\mathrm{CO}_{2}$ emission would be 

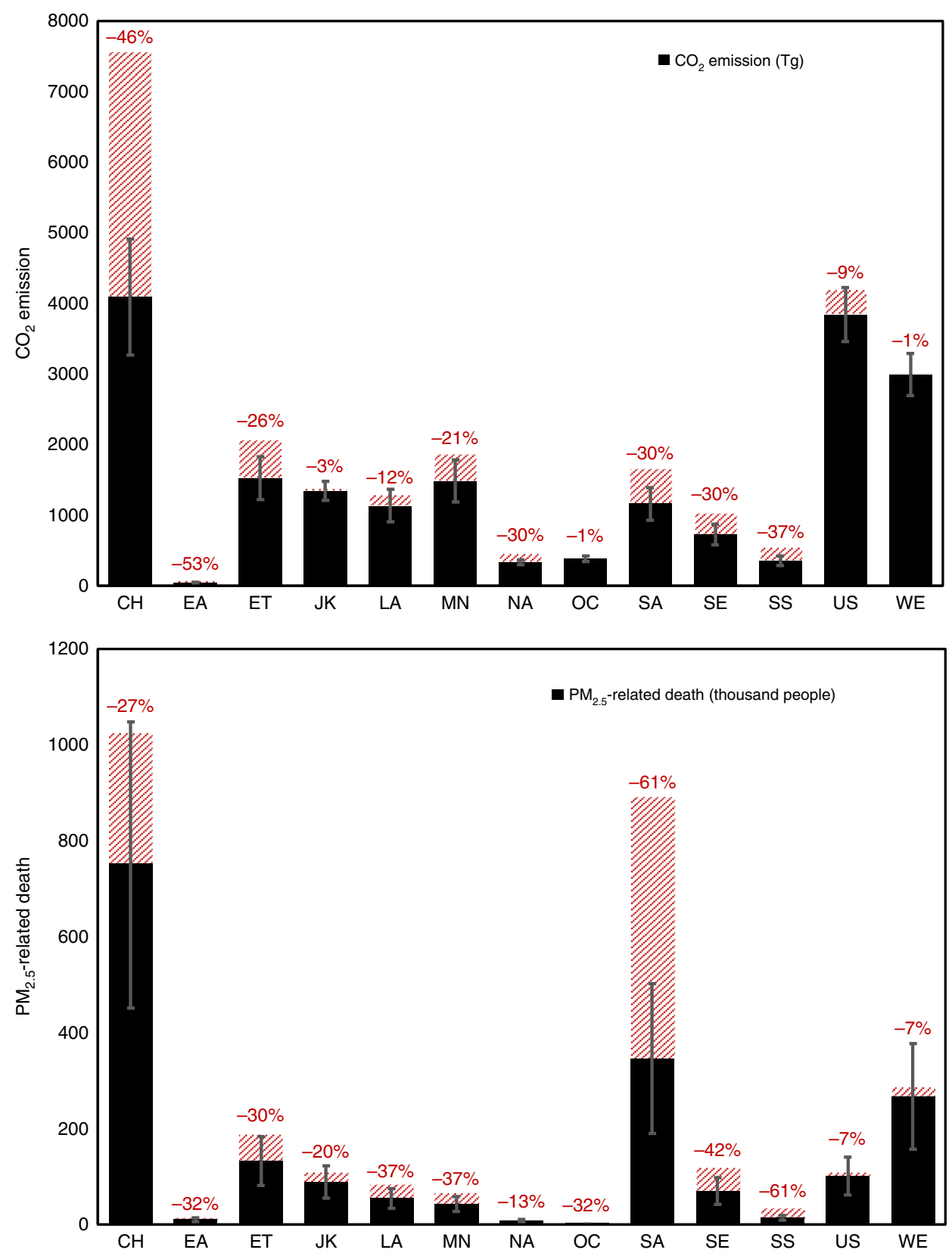

Fig. 4 Regional $\mathrm{CO}_{2}$ emission, $\mathrm{PM}_{2.5}$-related premature mortality under global free trade plus technological/financial support scenario (GFTT). Error bars denote uncertainty ranges $(95 \% \mathrm{Cl})$. Red dashed bars denote the amounts of respective reductions from global free trade scenario (GFT). Results here only include scenario-dependent sources. Regions, include China (CH), rest of East Asia (EA), Economies in Transition (ET), Japan and Korea (JK), Latin America and Caribbean (LA), Middle East and North Africa (MN), rest of North America (NA), Oceania (OC), South Asia (SA), South-East Asia and Pacific (SE), Sub-Saharan Africa (SS), the United States (US), and Western Europe (WE)

reduced by $46.0 \%$ in China and $30.4 \%$ in South Asia, and $\mathrm{PM}_{2.5^{-}}$ related mortality would be reduced by $61.1 \%$ in South Asia and $60.8 \%$ in sub-Saharan Africa.

Several sources of uncertainty and limitation exist in our study, as detailed in Methods. The standard GTAP model is an equilibrium model that does not simulate the temporal evolution of the economies. Emission data are subject to large errors especially for air pollutants. We do not account for the change in emission intensity of a given sector from one trade scenario to another, although the overall sectorally averaged emission intensity (i.e., total emission divided by total output from all sectors) is allowed to change because of the change in sectoral output structure. GEOS-Chem simulations are subject to errors in emissions and model representations of atmospheric chemical and physical processes. In particular, secondary organic aerosols (SOA) $)^{33-35}$ are not simulated here, considering the relative small contribution of anthropogenic SOA to the total $\mathrm{PM}_{2.5}{ }^{36-39}$. Using chemical efficiencies to calculate pollution levels for each trade scenario further introduces a minor source of error. For each scenario, a major source of error arises from the pollution-health exposure models used here. Quantitative estimates of these errors are given in Methods. The overall error results are expressed as $95 \% \mathrm{CI}$ in the main text. Although errors in emissions and pollution-health models are dominant, they are derived from causes that do not depend on trade scenarios, and are thus not relevant when discussing the relative change in premature mortality from one trade scenario to another. 
Over the past few decades, trade has been associated with movement of pollution-prone economic production from developed to developing regions ${ }^{26}$. This movement is continuing as production is being relocated from wealthier to poorer, developing regions ${ }^{40}$. Given the substantial gap in emission intensity between developed and developing regions, this movement might have meant a less environmentally friendly global economy, causing an unnecessary dilemma between trade-associated economic development and environmental sustainability ${ }^{41}$. Eliminating this dilemma will require substantial reductions in emission intensities in developing regions, crucially through local effort, global collaboration, and other collective action against environmental degradation. To this end, our study offers insight for policymakers who might consider to better address in trade negotiations the potential environmental implications of trade to ensure sustainable growth on regional and global scales.

\section{Methods}

An interdisciplinary framework. Our interdisciplinary approach to calculating the carbon and pollution health impacts of trade restrictions consists of a few steps. Supplementary Fig. 8 shows the overall framework.

First, we design five scenarios ranked by the extent of trade restrictions between 31 regions across 20 industrial sectors worldwide. Second, we use the GTAP computable general equilibrium (CGE) model $^{14,16}$ to simulate sector-specific interregional trade flows as well as other economic indicators and $\mathrm{CO}_{2}$ emissions.

Third, we calculate anthropogenic emissions of air pollutants specific to each trade scenario, by combining GTAP-modeled scenario-specific economic output and a prescribed, scenario-invariant dataset of emission intensities (i.e., emissions per monetary unit of economic output). The prescribed emission intensity data are specific to each pollutant in each of the 20 sectors in 31 regions, and are calculated based on economic output data in Scenario ATR (that represents the actual global economy in 2014) and a customized anthropogenic emission inventory. The inventory is from the $\mathrm{CEDS}^{17}$, with some improvements for China ${ }^{18,42-44}$.

Fourth, we use simulations of the GEOS-Chem model ${ }^{19}$ to derive near-surface $\mathrm{PM}_{2.5}$ mass concentrations for individual trade scenarios. The 31 emission source regions above are further aggregated into 13 regions (Supplementary Fig. 9) to reduce computational costs.

Finally, we apply the $\mathrm{PM}_{2.5}$ concentrations derived above to the GEMM ${ }^{21}$ to evaluate the health impacts in each trade scenario. Mortality results based on the integrated exposure-response model (IER) ${ }^{45}$ are also presented in Supplementary Data 2 for comparison. Results for the 13 aggregated regions are discussed in the main text.

Trade scenarios. Scenario GFT represents a world with no trade restrictions. In this scenario, the tariffs on all commodities in all regions are set to zero.

Scenario ATR represents the Actual Trade Restriction in 2014, according to the tariff and other economic data in the GTAP v10 database ${ }^{15,46}$. Supplementary

Table 1 shows the tariff setting.

Scenario TW1 represents the stage of the Sino-US trade war as of 2018. At this stage, the US imposes a $25 \%$ additional tariff on 728 specific products imported from China that are worth $\$ 50$ billion in total ${ }^{47}$, and a $10 \%$ additional tariff on 5745 items imported from China that are worth $\$ 250$ billion together ${ }^{48}$. Meanwhile, China imposes a $25 \%$ additional tariff on 659 specific products imported from the USA that together are worth $\$ 50$ billion ${ }^{10,49}$, and a $10 \%$ additional tariff on $2493+1078$ items and a $5 \%$ additional tariff on $974+662$ items imported from the USA that together are worth $\$ 60$ billion $^{11}$.

Thus, Scenario TW1 assumes that on top of Scenario ATR, the USA imposes additional tariffs on about $\$ 274$ billion worth of products imported from China, and China imposes additional tariffs on about $\$ 116$ billion worth of products from the USA. Supplementary Table 2 shows the tariff setting.

Eq. (1) shows how the sector-specific tax rates are converted from productbased rates. In reality, all products are classified based on the eight-digit subheadings of the Harmonized Tariff Schedule of the USAs and China. In our study, products are classified based on the 6-digit subheadings from UN Comtrade Database ${ }^{50}$ and then mapped to the 20 industrial sectors. Because of this productto-sector conversion, the monetary volumes of imported products with imposed tariffs in this scenario ( $\$ 274$ billion and $\$ 116$ billion) are slightly different from the actual volumes ( $\$ 250$ billion and $\$ 110$ billion). Another likely cause of such differences is that we use the actual trade data in 2014 rather than those in 2018, with slightly different trade and tariff information. The imposed tariff on each industrial sector in GTAP is calculated by

$$
T=V^{\prime} / V \times T^{\prime}
$$

Here, $T^{\prime}$ and $V^{\prime}$ denote the imposed tax rate and associated trade volume for each product belonging to a particular sector studied here. $T$ and $V$ denote the imposed tariff and associated trade volume in each of the 20 sectors studied here. Data of $T$
$(25 \%, 10 \%$, or $5 \%)$ are taken from reports by the USA Trade Representative and the Ministry of Finance of the People's Republic of China ${ }^{10,11,47-49}$. Data of $V$ ' and $V$ are from the UN Comtrade Database ${ }^{50}$.

Scenario TW2 represents the potential full-blown stage of the Sino-US trade war. This scenario, which is built upon scenario ATR, assumes that the Sino-US trade war intensifies to the extent that both the US and China impose an additional $25 \%$ tariff on all goods imported from each other. Supplementary Table 2 shows the tariff setting.

Scenario GTB represents a world in which every region moves strongly against trade such that on top of Scenario ATR, each region imposes an additional 25\% tariff on all products imported from all other regions. Supplementary Table 2 shows the tariff setting. This scenario is highly unlikely to happen in the near future. Nonetheless, the on-going anti-globalization movement in many countries $^{51,52}$ suggests that intensive trade wars might also occur between countries other than the USA and China, providing some rationale for this extreme scenario.

The GTAP model. The GTAP CGE model is a multiregional, multi-sector economic equilibrium model. With a long history of systematic improvements, GTAP provides an effective tool for a variety of studies related to trade, the environment population, energy, and climate change ${ }^{53-60}$. The model is a comparative static analysis model, assuming that the market is completely competitive and the returns to scale of production remain unchanged ${ }^{14}$. Taking these theoretical assumptions, producers are assumed to maximize profits, while consumers maximize their utility. The total supply and total demand are in equilibrium, and they together determine the values of endogenous variables, such as price, wages, and land rents. All economies (countries and regions) connect with each other through commodity trade.

Each production activity is a combination of intermediate goods and factors to produce output. Similar to many CGE models, the production structure inside GTAP is based on a sequence of nested constant elasticity of substitution (CES) functions that aims to reproduce the substitution possibilities across the full set of inputs. The top-level nest is composed of two aggregate composite bundles, i.e., intermediate demand and value added. The second level nest decomposes each of the two aggregate composite bundles into their components, such that one is demand for individual intermediate goods and the other is demand for primary factors. The final nest accepts the Armington assumption to allow an incomplete substitution between domestically produced goods and imported goods.

For private households, the particular functional form chosen here to represen preferences is based on the constant differences of elasticities implicit additive expenditure function by Hanoch ${ }^{61}$. The Cobb-Douglas function is adopted for depiction of government consumption. The sub-utility function for investment expenditure, i.e., gross investment, is based on a Leontief utility function. The aggregate volume of investment comes from the nominal investment equals saving identity, where saving is the sum of domestic saving and net capital inflows from foreign economies. Investment expenditures on the composite goods are subsequently decomposed into demand for domestic and imported goods using a CES sub-utility preference function.

In addition, GTAP includes five types of primary factors including land, capital, skilled labor, unskilled labor, and natural resources, and three representative agents including private households, governments, and companies. Within each country or region, the GTAP model allows capital and labor to move between production sectors, and partially allows land to move between crop producing sectors based on the CET assumptions.

The GTAP CGE model used here is built based on the latest version (v10) of the GTAP database ${ }^{15}$, which is constructed from the input-output tables of 141 countries and regions across the world with a base year of 2014. The GTAP database contains 57 sectors and 5 primary production factors. For this study, the 141 countries and regions have been aggregated to 31 regions, which specify major producers, consumers, and importers/exporters (see the mapping in Supplementary Data 3). The 57 production sectors are aggregated to a total of 20 sectors (see the mapping in Supplementary Data 3). The five types of original primary factors have been aggregated to three categories (land, capital, and labor).

Anthropogenic emissions of $\mathbf{C O}_{\mathbf{2}}$. For each scenario, anthropogenic emissions of $\mathrm{CO}_{2}$ are computed from the GTAP model. These emissions are calculated based on sector-specific emission factors (embedded in the GTAP database and unchanged across the trade scenarios) and scenario- and sector-specific energy consumption data computed from the GTAP model.

Anthropogenic emissions considered here are due to fuel combustion associated with economic production (i.e., those which directly produce GDP), except international shipping and aircraft emissions. These emissions vary from one trade scenario to another. Although different trade scenarios may affect emissions from international shipping and aircraft, these emissions are not accounted for here, due to lack of robust methods to allocate these emissions to specific regions. Emissions from residential activities (such as heating and cooking at home) and private transport are not included here. The process-related emissions (such as cement production) are not included here. Together, the sources not analyzed here contribute $9.9 \mathrm{Pg}$ of global $\mathrm{CO}_{2}$ emission ${ }^{15,62}$. 
Anthropogenic emissions of air pollutants. The GTAP model does not provide emissions of air pollutants. Thus, we calculate anthropogenic air pollutant emissions for each trade scenario based on prescribed sector-, region-, and pollutantspecific emission intensity data (that remain unchanged across the trade scenarios) and scenario-specific economic output from GTAP.

We derive the sector-, region-, and species-specific emission intensities by combining a customized emission inventory (CEDS+Xia, see below) in 2014 and economic output data in the GTAP database in 2014

We use the monthly gridded $\left(0.5^{\circ}\right.$ longitude $\times 0.5^{\circ}$ latitude) CEDS inventory ${ }^{17}$ for global anthropogenic emissions of gaseous $\left(\mathrm{SO}_{2}, \mathrm{NO}_{\mathrm{x}}, \mathrm{NH}_{3}, \mathrm{NMVOC}\right.$, and $\left.\mathrm{CO}\right)$ and primary aerosol (BC and OC) pollutants worldwide in 2014, with 54 sectors in 152 regions. The CEDS inventory has a globally consistent and reproducible methodology applied to all pollutants and includes updated emission factors ${ }^{17}$. It provides very detailed sectoral emission information, which is essential for this study. The inventory is being used by the Coupled Model Intercomparison Project Phase 6 (CMIP6, a main model support for the Inter-governmental Panel on Climate Change Sixth Assessment Report) and many other studies ${ }^{63-67}$.

The CEDS inventory uses regional emission data over the US (1990-2014), Canada (1990-2013), Europe (1980-2013), China (2008, 2010, and 2012), and other regions to revise its initial global methodology. Over the past decade, the amount of emissions in China varied significantly from 1 year to another due to implementation of stringent emission control measures as well as the changing economy and fossil fuel consumption. Thus, we replace the seasonal and spatial patterns of Chinese $\mathrm{SO}_{2}, \mathrm{NO}_{x}, \mathrm{CO}, \mathrm{BC}$, and POA emissions in CEDS by those in the MEIC inventory in $2014^{68}$. We further scale Chinese annual $\mathrm{SO}_{2}, \mathrm{NO}_{x}, \mathrm{CO}, \mathrm{BC}$, and POA emissions in CEDS to match those developed by Xia et al. ${ }^{18,42-44}$, which account for the pollution control measures more comprehensively and may better represent the actual emissions in China in 2014. Since the CEDS and Xia et al. inventories contain different sectors, we conduct a sector mapping procedure (Supplementary Data 4). Hereafter, we refer to this hybrid inventory as CEDS+Xia.

The CEDS + Xia inventory contains 54 sectors in 152 countries/regions. Of these sectors, 8 belong to energy production, 23 belong to industry, 8 belong to transportation, 4 belong to residential, 5 belong to agriculture, 4 belong to waste treatment, and the remaining 2 represent other unspecified processes that are associated with very few emissions. The inventory is a global monthly gridded dataset at a $0.5^{\circ}$ longitude $\times 0.5^{\circ}$ latitude resolution, beneficial for subsequent GEOS-Chem simulations.

The CEDS+Xia inventory contains activities that produce significant amounts of emissions but do not directly produce economic output, i.e., these activities do not produce GDP directly and are not included in the GTAP model. In linking the emission inventory and GTAP, we exclude these activities to better quantify the sector-specific emission intensities. Nonetheless, these emissions are included in GEOS-Chem simulations to derive the total (anthropogenic + natural) $\mathrm{PM}_{2.5}$.

First, emissions from the four sectors related to residential activities in CEDS + Xia are excluded, because these activities do not produce economic output accounted for in GTAP. This procedure was done also in previous studies $2,3,6$

The transportation sector in the CEDS + Xia inventory does not separate emissions associated with commercial vehicles from emissions associated with private vehicles. Private transport does not produce economic output accountable in GTAP, as opposed to commercial transport. Thus, we exclude emissions from private vehicles from the trade scenario analysis. This procedure improves upon previous studies that did not differentiate private and commercial transport ${ }^{2,3,6}$.

To differentiate emissions associated with private and commercial transport, we use the vehicle emission data from the greenhouse gas and air pollution interactions and synergies (GAINS) model. The GAINS model provides transportation related emissions from four vehicle types, including passenger cars, light duty vehicles, heavy duty vehicles and buses, mopeds, and motorcycles (Supplementary Table 3).

We derive the contribution of private transport to the total transportationrelated emissions as follows:

$$
F C_{\mathrm{r}, \mathrm{p}}=\frac{\sum E_{\mathrm{r}, \mathrm{s}}^{\mathrm{pr}}}{\sum E_{\mathrm{r}, \mathrm{p}}^{\mathrm{pr}}+\sum E_{\mathrm{r}, \mathrm{p}}^{\mathrm{co}}}
$$

Here, $\mathrm{FC}_{\mathrm{r}, \mathrm{p}}$ represents the fractional contribution of private vehicle driving for a given pollutant species $\mathrm{p}$ in a given region $\mathrm{r}$. $E_{\mathrm{r}, \mathrm{p}}^{\mathrm{pr}}$ and $E_{\mathrm{r}, \mathrm{p}}^{\mathrm{co}}$ represent emissions of species $\mathrm{p}$ in region $\mathrm{r}$ from private and commercial vehicle driving, respectively, in the GAINS model.

The GAINS model only covers 74 regions. For a region with no GAINS data, $\mathrm{FC}_{\mathrm{r}, \mathrm{p}}$ from its neighbor regions are employed. Supplementary Data 5 shows the fractional contribution of private vehicle driving $\mathrm{FC}_{\mathrm{r}, \mathrm{p}}$ in each region.

Based on the CEDS+Xia inventory, we derive a prescribed dataset for emission intensity that varies across the sectors, regions and pollutant species, by dividing the CEDS + Xia emissions by the economic output data in the GTAP database for 2014. This emission intensity dataset is used and remains unchanged in all trade scenarios.

We convert the CEDS+Xia emissions for 152 regions and 54 sectors to 141 regions and 57 sectors according to the original GTAP setup, and then to 31 regions and 20 sectors to match those in our trade scenario analyses. The mapping details are shown in Supplementary Data 6.
Subsequently, we calculate emission intensity for each pollutant in each of the 20 sectors and 31 regions

$$
F_{\mathrm{s}, \mathrm{r}, \mathrm{p}}^{\mathrm{b}}=E_{\mathrm{s}, \mathrm{r}, \mathrm{p}}^{\mathrm{b}} / X_{\mathrm{s}, \mathrm{r}}^{b}
$$

Here, the subscripts $s, r$, and $p$ denote the sector, region, and pollutant species, respectively. The superscript $b$ denotes the base year (2014) that has CEDS+Xia emissions $\left(E_{\mathrm{s}, \mathrm{r}, \mathrm{p}}^{b}\right)$ and economic output in the GTAP database for $2014\left(X_{\mathrm{s}, \mathrm{r}}^{b}\right)$.

For each trade scenario, trade scenario-dependent anthropogenic emissions $\left(E_{\mathrm{s}, \mathrm{t}, \mathrm{p}}^{\mathrm{c}}\right)$ are derived from the prescribed, scenario-invariant emission intensity $\left(F_{\mathrm{s}, \mathrm{r}, \mathrm{p}}^{b}\right)$ and scenario-specific economic outputs $\left(X_{\mathrm{s}, \mathrm{r}}^{c}\right)$

$$
\begin{aligned}
E_{\mathrm{s}, \mathrm{r}, \mathrm{p}}^{\mathrm{c}, \mathrm{t}} & =X_{\mathrm{s}, \mathrm{r}}^{\mathrm{c}} \times F_{\mathrm{s}, \mathrm{r}, \mathrm{p}}^{\mathrm{b}} \\
E_{\mathrm{r}, \mathrm{p}}^{\mathrm{c}, \mathrm{t}} & =\sum_{s} E_{\mathrm{s}, \mathrm{r}, \mathrm{p}}^{\mathrm{c}, \mathrm{p}} .
\end{aligned}
$$

Here, the subscripts $\mathrm{s}, \mathrm{r}$, and $\mathrm{p}$ denote the sector, region, and pollutant, respectively. The superscript $\mathrm{c}$ denotes the trade scenario, and $\mathrm{t}$ indicates that the emission is scenario-dependent. $E_{\mathrm{r}, \mathrm{p}}^{\mathrm{c}}$ denotes the emission summed over all of the 20 sectors. $E_{r, p}^{c, t}$ does not include emissions from residential activities and private vehicles.

Emissions from international shipping and aircraft are taken from other sources. Although different trade scenarios may affect these emissions, they are kept constant here, due to lack of robust methods to allocate these emissions to specific regions. As such, emission and pollution changes from one trade scenario to another discussed in this study do not include the changes in international shipping and aircraft. These emissions are not discussed in the main text. Nonetheless, these emissions are used in GEOS-Chem simulations to derive the total (anthropogenic + natural) $\mathrm{PM}_{2.5}$ discussed in next section.

GEOS-Chem simulations. Through a series of simulations of GEOS-Chem version $11-01^{19}$, we quantify the contributions of individual emission source regions on near-surface $\mathrm{PM}_{2.5}$ mass concentrations worldwide in each trade scenario. Given the expensive computational costs of GEOS-Chem, we aggregate the 31 GTAP regions into 13 emission source regions (see the mapping in Supplementary Table 4). Largely following previous studies ${ }^{3,6}$, the 13 regions are designed based on their economic status and geographical proximity.

$\mathrm{PM}_{2.5}$ species simulated by the model include SIOA (including sulfate, nitrate, and ammonium), $\mathrm{BC}$, primary organic aerosol (POA), SOA, anthropogenic dust, natural dust, and sea salt. SIOA, BC, POA, and SOA are derived from both anthropogenic and natural processes. Anthropogenic dust represents dusty particles emitted from industrial and transportation activities (i.e., chimneys of factories and pipes of vehicles). Natural dust and sea salt are emitted from natural processes.

In this study, we only analyze the changes in trade-related (and scenariodependent) anthropogenic SIOA, BC, and POA concentrations from one trade scenario to another. Emissions from residential activities and private transport remain unchanged across the trade scenarios, so do their impacts on ambient pollutant concentrations. Due to lack of data, anthropogenic dust is also kept constant across the trade scenarios. We do not include the trade scenario-related change in SOA concentrations, which are simulated poorly by current-generation models $s^{69}$. Natural SIOA, BC, POA, dust, and sea salt remain unchanged across the trade scenarios

The all-emission simulation of GEOS-Chem accounts for the impacts of all anthropogenic and natural emissions on $\mathrm{PM}_{2.5}$ worldwide in 2014. The simulation is run from June 2013 through December 2014, with the first seven months in 2013 used for model spin-up.

GEOS-Chem is driven by the year-specific GEOS-FP assimilated meteorology from the NASA Global Modeling and Assimilation Office (GMAO). The model is run with the full $\mathrm{O}_{x}-\mathrm{NO}_{x}-\mathrm{VOC}-\mathrm{CO}-\mathrm{HO}_{x}$ gaseous chemistry and online aerosol calculations on a $2.5^{\circ}$ longitude $\times 2^{\circ}$ latitude grid with 47 vertical layers, and each of the 10 lowest layers are about $130 \mathrm{~m}$ thick. Model convection follows the relaxed Arakawa-Schubert scheme ${ }^{70}$. Vertical mixing in the planetary boundary layer employs a non-local scheme implemented by Lin et al. ${ }^{71}$. Dry deposition follows Wesely ${ }^{72}$, with a number of modifications ${ }^{73}$, for gases and Zhang et al. ${ }^{74}$ for aerosols. Wet scavenging of soluble gases and aerosols follows Liu et al. ${ }^{75}$, with updates for BC.

Online calculation of SIOA employs the ISOROPIA-II thermodynamic equilibrium model ${ }^{76}$, with updates by Zhang et al. ${ }^{77}$ on catalytic heterogeneous sulfate formation and Heald et al..$^{78}$ on nitrate formation. Uptake of the hydroperoxyl radical on aerosols follows Lin et al. and Ni et al. ${ }^{79-81}$. Anthropogenic aromatics are represented by an increase in propene emissions ${ }^{79-81}$. The mass of POA is assumed to be 1.8 times that of primary organic carbon to account for oxygen atoms contained ${ }^{3}$. Calculation of SOA is parameterized by Pye and Seinfeld ${ }^{82}$

The all-emission simulation uses the CEDS+Xia inventory for global anthropogenic emissions of $\mathrm{NO}_{x}, \mathrm{SO}_{2}, \mathrm{NH}_{3}, \mathrm{NMVOC}, \mathrm{CO}, \mathrm{BC}$, and POA. Emissions of anthropogenic dust are taken from the MEIC inventory over China, and are assumed to be zero in other countries. Aircraft emissions are taken from $\mathrm{AEIC}^{83}$ for 2005. International shipping emissions are taken from ICOADS ${ }^{84}$ for $\mathrm{CO}$ and $\mathrm{NO}_{x}$, from $\mathrm{ARCTAS}^{85,86}$ for $\mathrm{SO}_{2}$ globally, and from EMEP ${ }^{87}$ for $\mathrm{SO}_{2}$ over European waters. Biomass burning emissions follow the GFED4 inventory ${ }^{88}$. Soil $\mathrm{NO}_{x}$ emissions follow Hudman et al. ${ }^{89}$. For lightning $\mathrm{NO}_{x}$ emissions, flash rates are 
calculated based on the cloud-top height and constrained by climatological satellite observations ${ }^{90}$, and the vertical profile of emitted $\mathrm{NO}_{x}$ follows Ott et al. ${ }^{91}$. Biogenic emissions of NMVOC follow the MEGAN v2.1 model $^{92}$. Natural dust particles are emitted with the DEAD scheme $\mathrm{e}^{93-95}$. The parameterization of sea salt emissions follows Jaégle et al. ${ }^{96}$.

Based on the CEDS + Xia inventory, we further conduct multiple sensitivity simulations based on the zero-out method $2,3,6,65$, to estimate the impacts of each region's anthropogenic pollutant emissions on $\mathrm{PM}_{2.5}$ concentrations worldwide. We conduct 13 sensitivity simulations (one for each source region), in which anthropogenic emissions of $\mathrm{NO}_{\mathrm{x}}, \mathrm{SO}_{2}, \mathrm{NH}_{3}, \mathrm{CO}, \mathrm{NMVOC}, \mathrm{BC}$, and $\mathrm{POA}$ in each region are removed. All other model setups are the same as in the all-emission simulation. The difference between the all-emission simulation and each sensitivity simulation represents the contribution of that region to $\mathrm{PM}_{2.5}$ worldwide. In addition, we conduct another sensitivity simulation, in which global anthropogenic emissions of air pollutants are excluded, to represent the natural contribution to the total $\mathrm{PM}_{2.5}$. Because we have no robust method to allocate emissions form international shipping and aviation into specific regions, emissions from these sectors are kept unchanged in all sensitivity simulations. Similar to the all-emission simulation, these sensitivity simulations are run from June 2013 through December 2014, with the first seven months in 2013 used for model spin-up.

GEOS-Chem simulations of $\mathrm{PM}_{2.5}$ have been validated by Zhang et al. ${ }^{3}$, Wang et al. ${ }^{97}$, and many other studies, by comparisons with ground, satellite and airborne measurements worldwide. Here we briefly compare the all-emission simulation to the satellite-derived surface $\mathrm{PM}_{2.5}$ data from Van Donkelaar et al. ${ }^{20}$. The satellite-derived $\mathrm{PM}_{2.5}$ data are estimated by combining satellite retrieved aerosol optical depth and GEOS-Chem, with further calibration based on global ground-based $\mathrm{PM}_{2.5}$ observations and geographically weighted regression. The satellite-derived data are regridded from its original resolution $\left(0.1^{\circ}\right.$ longitude $\times 0.1^{\circ}$ latitude $)$ to match the model resolution. Modeled $\mathrm{PM}_{2.5}$ concentration is the sum of SIOA, BC, POA, SOA, dust $(2 \times$ DST1 $+0.38 \times$ DST2 $)$, and sea salt (SALA). DST1, DST2, and SALA are the names of respective aerosol species in the model contributing to $\mathrm{PM}_{2.5}$, and only $38 \%$ of DST2 particle mass belong to $\mathrm{PM}_{2.5}$. Considering the large underestimate of natural dust by GEOS-Chem ${ }^{97,98}$, the simulated concentrations of fine natural dust particles (DST1) are scaled by a factor of 2 prior to the comparison.

Supplementary Fig. 10 compares the simulated, population-weight $\mathrm{PM}_{2.5}$ concentrations with the satellite-derived data for individual regions. Each data point represents a model grid cell. For each grid cell of a region (e.g., China), population weighting is done by multiplying the $\mathrm{PM}_{2.5}$ concentration of that grid cell by its fractional contribution to the averaged (over the grid cells) population of that region. Supplementary Fig. 10 shows that the simulated results are consistent with the observations, with $R^{2}$ of $0.82-0.99$ and relative mean biases of $2.5-13.0 \%$ across the regions.

We use the sum of anthropogenic $\mathrm{PM}_{2.5}$ contributed by each region and by global natural emissions (Eq. (6)) as the reference "total $\mathrm{PM}_{2.5}$ ", which is used later as a basis to evaluate the changes in $\mathrm{PM}_{2.5}$ and associated premature mortality from one trade scenario to another. This method, instead of using the $\mathrm{PM}_{25}$ concentrations in the all-emission simulation as the reference, removes the slight effect of chemical nonlinearity in source attribution ${ }^{3,65}$

$$
\begin{gathered}
C_{\mathrm{p}, \mathrm{i}}^{\mathrm{b}}=C_{\mathrm{n}, \mathrm{p}, \mathrm{i}}^{\mathrm{b}}+\sum_{\mathrm{r}=1}^{13} C_{\mathrm{r}, \mathrm{p}, \mathrm{i}}^{\mathrm{b}}, \\
C_{i}^{\mathrm{b}}=\sum_{\mathrm{p}} C_{\mathrm{p}, \mathrm{i}}^{\mathrm{b}} .
\end{gathered}
$$

Here, the superscript $b$ denotes the base case for 2014. The subscript $p$ denotes the $\mathrm{PM}_{2.5}$ species; $\mathrm{r}$ denotes the anthropogenic source region; $\mathrm{n}$ denotes the natural contribution; and i denotes the location (i.e., a model grid cell). $C_{\mathrm{r}, \mathrm{p}, \mathrm{i}}^{\mathrm{b}}$ represents the derived near-surface mass concentration of each $\mathrm{PM}_{2.5}$ species at each location contributed by anthropogenic emissions (from all sectors) in region r. $C_{r . p . i}^{b}$ is derived by subtracting the all-emission simulation by each sensitivity simulation with anthropogenic emissions in the respective source region excluded. $C_{\mathrm{n}, \mathrm{p}, \mathrm{i}}^{\mathrm{b}}$, which is produced from the sensitivity simulation with global anthropogenic emissions excluded, represents the natural $\mathrm{PM}_{2.5}$ concentration.

We also use model simulation results to establish the chemical efficiency $\left(\mathrm{CE}_{\mathrm{r}, \mathrm{p}, \mathrm{i}}^{\mathrm{b}}\right)$ of the atmosphere in converting emissions in each region to ambient $\mathrm{PM}_{2.5}$ concentrations worldwide

$$
\begin{gathered}
E_{\mathrm{r}, \mathrm{p}^{\prime}}^{\mathrm{b}}=\sum_{s} E_{\mathrm{s}, \mathrm{r}, \mathrm{p}}^{\mathrm{b}} \cdot \\
\mathrm{CE}_{\mathrm{r}, \mathrm{p}, \mathrm{i}}^{\mathrm{b}}=\frac{C_{\mathrm{r}, \mathrm{p}, \mathrm{i}}^{\mathrm{b}}}{E_{\mathrm{r}, \mathrm{p}^{\prime}}^{b}}
\end{gathered}
$$

Here, the subscript p' denotes the emitted species $\left(\mathrm{NO}_{x}+\mathrm{SO}_{2}+\mathrm{NH}_{3}, \mathrm{BC}\right.$, or POA), and $\mathrm{p}$ denotes the respective $\mathrm{PM}_{2.5}$ species (SIOA, $\mathrm{BC}$, or POA). The subscript $\mathrm{i}$ denotes the location (i.e., a model grid cell). The superscript $b$ denotes the base case for 2014. $E_{\mathrm{r}, \mathrm{p}^{\prime}}^{\mathrm{b}}$ represents the total anthropogenic emission of species $\mathrm{p}^{\prime}$ in region $\mathrm{r}$. $\mathrm{CE}_{\mathrm{r}, \mathrm{p}, \mathrm{i}}^{\mathrm{b}}$ represents the chemical efficiency specific to each source region and $\mathrm{PM}_{2.5}$ species, and it remains the same from one trade scenario to another. Following Wang et al. ${ }^{97}$, for SIOA, the chemical efficiency is calculated by dividing the concentration of SIOA by the sum of emissions of $\mathrm{NO}_{x}$ (expressed in terms of nitrate), $\mathrm{SO}_{2}$ (expressed in terms of sulfate) and $\mathrm{NH}_{3}$ (expressed in terms of ammonium), considering the thermodynamic equilibrium of these species. See Supplementary Fig. 4 for more details.

For each scenario, the total $\mathrm{PM}_{2.5}$ is contributed by four components: (1) natural aerosols, (2) anthropogenic dust and anthropogenic SOA, (3) anthropogenic but trade scenario-independent SIOA, BC, and POA (i.e., from residential and private vehicle emissions), and (4) trade scenario-dependent SIOA, $\mathrm{BC}$, and POA. Only the last component varies from one trade to another.

To calculate the trade scenario-dependent SIOA, BC, and POA for each trade scenario and source region, we use the prescribed chemical efficiency $\mathrm{CE}_{\mathrm{r}, \mathrm{p}, \mathrm{i}}^{\mathrm{b}}$ to convert the scenario- and source region-specific anthropogenic pollutant emissions to respective gridded concentrations worldwide $\left(C_{\mathrm{r}, \mathrm{p}, \mathrm{i}}^{\mathrm{c}, \mathrm{i}}\right.$ and $C_{\mathrm{r}, \mathrm{i}}^{\mathrm{ct}}$ in Eqs. (10) and (11)).

$$
\begin{aligned}
C_{\mathrm{r}, \mathrm{p}, \mathrm{i}}^{\mathrm{ct}} & =\mathrm{CE}_{\mathrm{r}, \mathrm{p}, \mathrm{i}}^{\mathrm{b}} \times E_{\mathrm{r}, \mathrm{p}{ }^{\prime}}^{\mathrm{c}, \mathrm{t}} \\
C_{\mathrm{r}, \mathrm{i}}^{\mathrm{c}, \mathrm{t}} & =\sum_{p} C_{\mathrm{r}, \mathrm{p}, \mathrm{i}}^{\mathrm{c}, \mathrm{t}}
\end{aligned}
$$

Here, $C_{r, p, i}^{c, t}$ only accounts for trade scenario-dependent anthropogenic SIOA, BC, and POA that vary across the individual trade scenarios. The subscript $r$ denotes the source region, $\mathrm{p}$ the $\mathrm{PM}_{2.5}$ species (SIOA, BC, or POA), and i the grid cell. The superscript $\mathrm{c}$ denotes the trade scenario, and $\mathrm{t}$ indicates that this concentration is trade scenario-dependent and is accounted for here.

For the other three $\mathrm{PM}_{2.5}$ components that do not vary with trade scenarios, their sum is calculated as follows

$$
C_{i}^{\mathrm{c}, \mathrm{o}}=C_{\mathrm{i}}^{\mathrm{b}}-\sum_{\mathrm{r}} C_{\mathrm{r}, \mathrm{i}}^{\mathrm{b}, \mathrm{t}}
$$

Here, the superscript $b$ represents the base case in 2014 (i.e., Scenario ATR), and o indicates the sum of the other three components. Thus, for the total $\mathrm{PM}_{2.5}$ in each trade scenario

$$
C_{\mathrm{i}}^{\mathrm{c}}=\sum_{\mathrm{r}} C_{\mathrm{r}, \mathrm{i}}^{\mathrm{c}, \mathrm{t}}+C_{\mathrm{i}}^{\mathrm{c}, \mathrm{o}} .
$$

Prior to calculating the health impacts of $\mathrm{PM}_{2.5}$, we eliminate the systematic bias in modeled $\mathrm{PM}_{2.5}$ concentrations related to errors in model physics and chemistry and errors in emission inputs. Simultaneously, we reproject the $\mathrm{PM}_{2.5}$ concentrations from a $2.5^{\circ}$ longitude $\times 2^{\circ}$ latitude grid to a $0.1^{\circ}$ longitude $\times 0.1^{\circ}$ latitude grid. We first calculate the ratio of the satellite-derived $\mathrm{PM}_{2.5}$ concentrations to the modeled $\mathrm{PM}_{2.5}$ in the all-emission simulation (Eq. (14)), and then apply the ratio to all trade scenarios (Eqs. (15) and (16)). This procedure ensures that the scenario-specific results are corrected to allow a more accurate health impact estimate.

$$
\begin{aligned}
R_{\mathrm{j}}^{\mathrm{b}} & =C_{\mathrm{j}}^{\mathrm{m}} / C_{\mathrm{i}}^{\mathrm{b}} . \\
\mathrm{C}_{\mathrm{j}}^{\mathrm{c}} & =R_{\mathrm{j}}^{\mathrm{b}} \times C_{\mathrm{i}}^{\mathrm{c}} . \\
\mathrm{C}_{\mathrm{r}, \mathrm{j}}^{\mathrm{c}, \mathrm{t}} & =R_{\mathrm{j}}^{\mathrm{b}} \times C_{\mathrm{r}, \mathrm{i}}^{\mathrm{c}, \mathrm{t}} .
\end{aligned}
$$

Here, $C_{j}^{\mathrm{m}}$ represents the satellite-based $\mathrm{PM}_{2.5}$ concentration at a $0.1^{\circ} \times 0.1^{\circ}$ grid cell j. $\mathrm{C}_{j}^{\mathrm{c}}$ represents the adjusted total $\mathrm{PM}_{2.5}$ concentration at a $0.1^{\circ} \times 0.1^{\circ}$ grid cell $\mathrm{j}$, with respect to the pre-adjusted total $\mathrm{PM}_{2.5}\left(C_{\mathrm{i}}^{\mathrm{c}}\right)$ at a $2.5^{\circ} \times 2^{\circ}$ grid cell $\mathrm{i}$, in each trade scenario. The center of the finer grid cell $j$ is within the coarser grid cell i. $\mathrm{C}_{\mathrm{r}, \mathrm{j}}^{\mathrm{cct}}$ represents the adjusted, trade scenario-dependent $\mathrm{PM}_{2.5}$ concentration (summed over SIOA, $\mathrm{BC}$, and $\mathrm{POA}$ ) at each $0.1^{\circ} \times 0.1^{\circ}$ grid cell contributed by each source region in each trade scenario.

Premature deaths due to ambient $\mathbf{P M}_{\mathbf{2 . 5}}$ exposure. We use the GEMM developed by Burnett et al. ${ }^{21}$ to estimate $\mathrm{PM}_{2.5}$-induced premature deaths in each trade scenario. The GEMM model represents an update upon the IER model used in GBD studies ${ }^{99}$. Both GEMM and IER account for five causes of mortality: ischemic heart disease, stroke, chronic obstructive pulmonary disease, lung cancer, and lower respiratory infections (LRIs). The accounting method in GEMM based on five individual causes is referred to as GEMM 5COD. The GEMM also offers an alternative accounting method (GEMM NCD+LRI) that combines all noncommunicable diseases and LRIs ${ }^{21}$.

The main text presents our estimated $\mathrm{PM}_{25}$ induced mortality results based on the GEMM NCD+LRI method. Results based on GEMM 5COD and IER are also presented in Supplementary Data 2 for comparison.

We first apply the above pollution-health models to the adjusted total $\mathrm{PM}_{2.5}$ concentrations in each scenario $\left(\mathrm{C}_{\mathrm{j}}^{\prime \mathrm{c}}\right)$ to derive $\mathrm{PM}_{2.5}$-related premature deaths worldwide on a $0.1^{\circ}$ longitude $\times 0.1^{\circ}$ latitude grid $\left(D_{\mathrm{j}}^{\mathrm{c}}\right)$. Detailed models and parameters to calculate $D_{j}^{c}$ are presented in Supplementary Data 2. The countrybased baseline mortality data for each disease are from the GBD 2016 health data. The gridded population data on a $0.1^{\circ} \times 0.1^{\circ}$ spatial resolution are also taken from GBD 2016 health data. To estimate the age-specific health impacts, we employ the country-based age structure from the Unite Nations population data, with the assumption that the age-structure remains unchanged within each region. Based on the country-based baseline mortality, the population data and the age-structure data, we calculate, grid cell by grid cell, the age-specific baseline mortality rate 
which equals to the baseline mortality divided by the total population in specific age. When applying the gridded baseline mortality rate data to our health impacts calculation, we assume that the baseline mortality rates remain unchanged across the trade scenarios.

We then use the widely-used direct proportion approach ${ }^{3,100-102}$ to assign the fraction of mortality caused by trade scenario-dependent $\mathrm{PM}_{2.5}$ (summed over SIOA, BC, and POA) contributed by each source region in each trade scenario $\left(D_{\mathrm{r}, \mathrm{j}}^{\mathrm{c} t}\right.$ in Eq. (17)). The direct proportion approach assumes that the contribution of one source to the disease burden of air pollution is directly proportional to its share of the total $\mathrm{PM}_{2.5}$ concentration $3,100-102$.

$$
D_{\mathrm{r}, \mathrm{j}}^{\mathrm{c}, \mathrm{t}}=D_{\mathrm{j}}^{\mathrm{c}} \times \frac{\mathrm{C}_{\mathrm{r}, \mathrm{j}}^{\mathrm{c}, \mathrm{t}}}{C_{\mathrm{j}}^{\prime c}} .
$$

Supplementary Data 2 compares our global mortality results in Scenario ATR (which represent the actual situation in 2014) with those by Burnett et al. ${ }^{21}$. There is a slight difference $(20 \%)$ in global mortality. This is in part because we use an updated version of baseline mortality data upon Burnett et al. In addition, we calculate the mortality for individual grid cells based on their $\mathrm{PM}_{2.5}$ concentrations, instead of applying the national average $\mathrm{PM}_{2.5}$ concentration to the pollutionhealth response model, as done by Burnett et al. ${ }^{21}$.

Uncertainty estimates. Our study is subject to uncertainties from a few sources. First, the GTAP model calculates the changes in global and regional economies from one equilibrium state to another, without considering the temporal (dynamic) evolution of the economies. This means that the model results cannot be compared directly to the economic changes shown in the real economic statistical data. Nonetheless, our model results are consistent with independent economic estimates for various stages of the Sino-US trade war (Supplementary Table 1), which provides confidence in using GTAP for trade scenario analyses.

Second, estimates of emissions are subject to errors in the amount of activity data (e.g., the amount of coal burnt) and emission factors (e.g., the amount of emission per unit of coal burnt) ${ }^{103}$. The overall uncertainty in $\mathrm{CO}_{2}$ emissions is relatively small (within 5\% for industrialized countries and within 5-15\% for developing regions $)^{62,104}$, compared to the uncertainty in air pollutant emissions. We assign the same errors to $\mathrm{CO}_{2}$ emissions in all scenarios.

Third, estimates of air pollutant emissions are affected by errors in emission factors, which rely on the estimate of the level of end-of-pipe emission control, and errors in activity data. The uncertainties in CEDS $^{17}$ and Xia et al. ${ }^{18,42-44}$ inventories are discussed in detail elsewhere. We adopt the error estimates from previous work for the 13 regions studied here ${ }^{3,6}$. These errors approximately range from 10 to $170 \%$ depending on the pollutant and region (Supplementary Fig. 1). For health impact calculations, these errors are implicit in the derivation of the $\sigma 2$ error below.

Fourth, implementation of the different levels of trade restrictions may affect the energy efficiency and energy source (e.g., coal and solar) in each region and sector. This means that the emission intensity for a given sector may change from one trade scenario to another. This information is partly lost due to our sectoral aggregation. For example, we only have one sector for "Electricity" and thus the fuel mix change cannot be accounted for. A higher level of disaggregation would have the fuel mix changes endogenously included. Although one could exogenously include some sort of efficiency improvement based on extrapolation of previous trends, the approach is subject to the availability of historical data and the appropriateness of extrapolation. Thus we assume that for each region and species, emission intensity of a given sector does not change across the trade scenarios. Nonetheless, the overall emission intensity (i.e., total emission divided by total output from all sectors) is allowed to change because of the change in sectoral output structure (Supplementary Fig. 7). This simplified approach may lead to an additional uncertainty in the calculated emissions. For each scenario other than ATR, the uncertainty is tentatively assigned as $\sigma 1=5 \%$ (one standard deviation), given the amount of fractional change in the global GDP from one scenario to another. $\sigma 1=0$ for Scenario ATR which uses the actual economic data in 2014 .

Fifth, as discussed in previous studies ${ }^{3,6}$, GEOS-Chem simulations are subject to errors in emissions and model representations of atmospheric chemical and physical processes such as dry deposition, wet scavenging, transport, and formation of secondary aerosols. A full evaluation of model uncertainties is computationally prohibitive ${ }^{3,6}$. However, GEOS-Chem simulations of $\mathrm{PM}_{25}$ have been validated by comparisons with a comprehensive set of observations ${ }^{3}$, and have been adjusted in this study to match the satellite-based $\mathrm{PM}_{2.5}$ data. Thus, following Zhang et al. ${ }^{3}$, we use the normalized root-mean-square deviation (NRMSD) between the modeled (in the all-emission simulation) and the satellite-based population-weighted $\mathrm{PM}_{2.5}$ concentrations to represent the overall model errors for each region (See Supplementary Fig. 10). The error is referred to as $\sigma 2$ (one standard deviation), which accounts for the combined effects of random errors in emissions and errors in model representations of atmospheric processes.

Sixth, for each trade scenario, we use prescribed region- and species-specific chemical efficiency data to convert from pollutant emissions to ambient concentrations. The chemical efficiency data are calculated based on model sensitivity simulations, and are assumed to be unchanged across the individual trade scenarios. This assumption may lead to slight errors for SIOA due to the thermodynamic interdependence between sulfate, nitrate and ammonium. Nonetheless, the magnitudes of chemical efficiency calculated by GEOS-Chem are comparable to results from other models ${ }^{105,106}$. An additional uncertainty related to the use of chemical efficiency arises from the fact that within each of the 13 emission source regions in GEOS-Chem simulations, there may be multiple GTAP regions, due to the mapping from 31 GTAP regions to 13 GEOS-Chem regions. This mean that the spatial pattern of emissions within each of the 13 regions may slightly change from one trade scenario. For each scenario other than ATR, we tentatively assign a $\sigma 3=15 \%$ error (one standard deviation) due to use of chemical efficiency. $\sigma 3=0$ for Scenario ATR, whose model results are the same as the base case of GEOS-Chem driven by the emissions in 2014.

Seventh, the pollution-health models used here (GEMM NCD+LRI, GEMM 5COD, and IER) are subject to large errors in linking pollution exposure, specific diseases, and premature death. In particular, the two GEMM models do not consider the potential differences in toxicity between the individual $\mathrm{PM}_{2.5}$ components. The accuracy of pollution-health models is also limited by the amount of cohort studies used to build the models ${ }^{21}$. To build the IER model, cohort studies related to not just ambient pollution but also indoor pollution and smoking are used ${ }^{101}$. To evaluate the uncertainty from pollution-health models, we calculate the mortality based on each of GEMM NCD+LRI, GEMM 5COD, and IER. Furthermore, for each model we calculate the $95 \%$ CI for the estimated mortality data, through a bootstrap method which incorporates both sampling and model shape uncertainty. The corresponding error (one standard deviation) is referred to as $\sigma 4$ (one standard deviation).

The overall uncertainty in the mortality data for each trade scenario is estimated as the sum in quadrature of $\sigma 1-\sigma 4$. Error results are expressed as $95 \% \mathrm{CI}$ in the main text. Although $\sigma 2$ and $\sigma 4$ are dominant sources of error, they are derived from causes that do not depend on trade scenarios. Thus, $\sigma 2$ and $\sigma 4$ are not relevant when discussing the relative change in premature mortality from one trade scenario to another.

\section{Data availability}

All data used here are cited in the text. The datasets generated during this study are available from the corresponding authors.

\section{Code availability}

All computer codes generated during this study are available from the corresponding authors upon reasonable request.

Received: 17 April 2019; Accepted: 30 September 2019; Published online: 30 October 2019

\section{References}

1. Hubacek, K., Feng, K., Minx, J. C., Pfister, S. \& Zhou, N. Teleconnecting consumption to environmental impacts at multiple spatial scales. J. Ind. Ecol. 18, 7-9 (2014).

2. Lin, J. et al. China's international trade and air pollution in the United States. Proc. Natl Acad. Sci. USA 111, 1736-1741 (2014).

3. Zhang, Q. et al. Transboundary health impacts of transported global air pollution and international trade. Nature 543, 705 (2017).

4. Davis, S. J. \& Ken, C. Consumption-based accounting of $\mathrm{CO}_{2}$ emissions. Proc. Natl Acad. Sci. USA 107, 5687-5692 (2010).

5. Oita, A. et al. Substantial nitrogen pollution embedded in international trade. Nat. Geosci. 9, 111 (2016).

6. Lin, J. et al. Global climate forcing of aerosols embodied in international trade. Nat. Geosci. 9, 790 (2016).

7. Copeland, B. R. \& Taylor, M. S. Trade, growth, and the environment. J. Econ. Lit. 42, 7-71 (2004).

8. Grossman, G. M. \& Krueger, A. B. Environmental impacts of a north american free trade agreement. Soc. Sci. Electron. Publ. 57, https://doi.org/10.3386/ w3914 (1991).

9. Nordström, H. \& Vaughan, S. Trade and the Environment. (World Trade Organization Publications, Geneva, 1999).

10. Office of the United States Trade Representative. USTR Issues Tariffs on Chinese Products in Response to Unfair Trade Practices, https://ustr.gov/ about-us/policy-offices/press-office/press-releases/2018/june/ustr-issuestariffs-chinese-products (2018).

11. Customs Tariff Commission of the State Council. Proclamation by Customs Tariff Commission of the State Council about Imposing Tarrifs on 60 Billions Dollars Imports Originating from the United States (in Chinese), http://gss.mof. gov.cn/zhengwuxinxi/zhengcefabu/201809/t20180918_3022592.html (2018).

12. Voituriez, T. \& Wang, X. Real challenges behind the EU-China PV trade dispute settlement. Clim. Policy 15, 670-677 (2015).

13. World Trade Organization (WTO). Panels Established to Review US Steel and Aluminium Tariffs, Countermeasures on US Imports. https://www.wto.org/ english/news_e/news18_e/dsb_19nov18_e.htm (2018). 
14. Hertel, T. W. Global Trade Analysis: Modeling and Applications. (Cambridge University Press, Cambridge, UK, 1997).

15. GTAP v10 Data Base (Pre-Released version). Available at: https://www.gtap. agecon.purdue.edu/about/project.asp (2019).

16. Corong, E. L., Hertel, T. W., McDougall, R., Tsigas, M. E. \& van der Mensbrugghe, D. The Standard GTAP Model, Version 7. Available at: https:// jgea.org/resources/jgea/ojs/index.php/jgea/article/view/47 (2017).

17. Hoesly, R. M. et al. Historical (1750-2014) anthropogenic emissions of reactive gases and aerosols from the Community Emissions Data System (CEDS). Geosci. Model Dev. 11, 369-408 (2018).

18. Xia, Y., Zhao, Y. \& Nielsen, C. P. Benefits of China's efforts in gaseous pollutant control indicated by the bottom-up emissions and satellite observations 2000-2014. Atmos. Environ. 136, 43-53 (2016).

19. GEOS-Chem v11-01. Available at: http://wiki.seas.harvard.edu/geos-chem/ index.php/Main_Page (2017).

20. Van Donkelaar, A. et al. Global estimates of fine particulate matter using a combined geophysical-statistical method with information from satellites, models, and monitors. Environ. Sci. Technol. 50, 3762-3772 (2016).

21. Burnett, R. et al. Global estimates of mortality associated with long-term exposure to outdoor fine particulate matter. Proc. Natl Acad. Sci. USA 115 , 9592-9597 (2018)

22. Giannakis, E. et al. Exploring the economy-wide effects of agriculture on air quality and health: evidence from Europe. Sci. Total Environ. 663, 889-900 (2019).

23. Aksoyoglu, S., Prévôt, A. S. H. \& Baltensperger, U. Contribution of ship emissions to the concentration and deposition of pollutants in Europe: seasonal and spatial variation. Atmos. Chem. Phys. 16, 1895-1906 (2016)

24. British Petroleum Company. BP Statistical Review of World Energy. Available at: https://www.bp.com/content/dam/bp/business-sites/en/global/corporate/ pdfs/energy-economics/statistical-review/bp-stats-review-2018-full-report.pdf (2018).

25. Quadrelli, R. \& Peterson, S. The energy-climate challenge: recent trends in $\mathrm{CO}_{2}$ emissions from fuel combustion. Energy Policy 35, 5938-5952 (2007).

26. Jakob, M. \& Marschinski, R. Interpreting trade-related $\mathrm{CO}_{2}$ emission transfers. Nat. Clim. Change 3, 19 (2012).

27. Geng, Y. et al. Recent trend of industrial emissions in developing countries. Appl. Energy 166, 187-190 (2016).

28. Du, Y. et al. A global strategy to mitigate the environmental impact of China's ruminant consumption boom. Nat. Commun. 9, 4133 (2018).

29. Lipsett-Moore, G. J., Wolff, N. H. \& Game, E. T. Emissions mitigation opportunities for savanna countries from early dry season fire management. Nat. Commun. 9, 2247 (2018).

30. UNFCCC. Adoption of the Paris Agreement. Report No. FCCC/CP/2015/L.9/ Rev.1. Available at: http://unfccc.int/resource/docs/2015/cop21/eng/109r01.pdf (2015).

31. Rogelj, J. et al. Paris Agreement climate proposals need a boost to keep warming well below $2{ }^{\circ} \mathrm{C}$. Nature 534, 631 (2016).

32. Economists' Statement on Carbon Dividends. Available at: https://www. clcouncil.org/economists-statement/ (2019)

33. Shrivastava, M. et al. Urban pollution greatly enhances formation of natural aerosols over the Amazon rainforest. Nat. Commun. 10, https://doi.org/ 10.1038/s41467-019-08909-4 (2019).

34. Shrivastava, M. K., Donahue, N. M., Pandis, S. N. \& Robinson, A. L. Effects of gas particle partitioning and aging of primary emissions on urban and regional organic aerosol concentrations. J. Geophys. Res. Atmos. 113, D18301 (2008)

35. Shrivastava, M. et al. Global transformation and fate of SOA: implications of low volatility SOA and gas-phase fragmentation reactions: global modeling of SOA. J. Geophys. Res. Atmos. 120, 4169-4195 (2015).

36. Chen, Q., Fu, T.-M., Hu, J., Ying, Q. \& Zhang, L. Modelling secondary organic aerosols in China. Natl Sci. Rev. 4, 806-809 (2017)

37. Fu, T. M. et al. Carbonaceous aerosols in China: top-down constraints on primary sources and estimation of secondary contribution. Atmos. Chem. Phys. 12, 2725-2746 (2012).

38. Jiang, F. et al. Regional modeling of secondary organic aerosol over China using WRF/Chem. J. Aerosol. Sci. 43, 57-73 (2012).

39. Volkamer, R. et al. Secondary organic aerosol formation from anthropogenic air pollution: rapid and higher than expected. Geophys. Res. Lett. 33, https:// doi.org/10.1029/2006gl026899 (2006).

40. Meng, J. et al. The rise of South-South trade and its effect on global $\mathrm{CO}_{2}$ emissions. Nat. Commun. 9, 1871 (2018).

41. Jiang, X., Guan, D. \& López, L. A. The global $\mathrm{CO}_{2}$ emission cost of geographic shifts in international sourcing. Energy Econ. 73, 122-134 (2018).

42. Zhao, Y., Nielsen, C. P., Lei, Y., McElroy, M. B. \& Hao, J. Quantifying the uncertainties of a bottom-up emission inventory of anthropogenic atmospheric pollutants in China. Atmos. Chem. Phys. 11, 2295-2308 (2011).

43. Zhao, Y., Nielsen, C. P., McElroy, M. B., Zhang, L. \& Zhang, J. CO emissions in China: uncertainties and implications of improved energy efficiency and emission control. Atmos. Environ. 49, 103-113 (2012).
44. Zhao, Y., Zhang, J. \& Nielsen, C. The effects of recent control policies on trends in emissions of anthropogenic atmospheric pollutants and $\mathrm{CO}_{2}$ in China. Atmos. Chem. Phys. 13, 487-508 (2013).

45. Burnett, R. T. et al. An integrated risk function for estimating the global burden of disease attributable to ambient fine particulate matter exposure. Environ. Health Perspect. 122, 397-403 (2014).

46. Aguiar, A., Narayanan, B. \& McDougall, R. An overview of the GTAP 9 data base. J. Glob. Econ. Anal. 1, 181-208 (2016).

47. Customs Tariff Commission of the State Council. Proclamation by Customs Tariff Commission of the State Council about Imposing Tarrifs on 50 Billions Dollars Imports Originating from the United States (in Chinese), http://gss. mof.gov.cn/zhengwuxinxi/zhengcefabu/201806/t20180616_2930325.html (2018).

48. Office of the United States Trade Representative. USTR Finalizes Tariffs on \$200 Billion of Chinese Imports in Response to China's Unfair Trade Practices, https://ustr.gov/about-us/policy-offices/press-office/press-releases/ 2018/september/ustr-finalizes-tariffs-200 (2018).

49. Office of the United States Trade Representative. USTR Finalizes Second Tranche of Tariffs on Chinese Products in Response to China's Unfair Trade Practices, https://ustr.gov/about-us/policy-offices/press-office/press-releases/ 2018/august/ustr-finalizes-second-tranche (2018).

50. United Nations. UN Comtrade Database. Available at: https://comtrade.un. org/data/ (2018)

51. List of demonstrations against corporate globalization. Available at: https://en. wikipedia.org/wiki/List_of_demonstrations_against_corporate_globalization (2018).

52. Ehrenberg, J. What can we learn from Occupy'soccupy's failure? Palgrave Commun. 3, 17062 (2017).

53. Schandl, H. et al. Decoupling global environmental pressure and economic growth: scenarios for energy use, materials use and carbon emissions. J. Clean. Prod. 132, 45-56 (2016).

54. Xie, W., Ali, T., Cui, Q. \& Huang, J. Economic impacts of commercializing insect-resistant GM maize in China. China Agr. Econ. Rev. 9, 340-354 (2017).

55. Konar, M., Reimer, J. J., Hussein, Z. \& Hanasaki, N. The water footprint of staple crop trade under climate and policy scenarios. Environ. Res. Lett. 11, 035006 (2016).

56. Boulanger, P. \& Philippidis, G. The EU budget battle: assessing the trade and welfare impacts of CAP budgetary reform. Food Policy 51, 119-130 (2015).

57. Breuss, F. WTO dispute settlement: an economic analysis of four EU-US mini trade wars-a survey. J. Ind. Compet. Trade 4, 275-315 (2004).

58. Kahsay, T. N., Kuik, O., Brouwer, R. \& van der Zaag, P. The transboundary impacts of trade liberalization and climate change on the Nile basin economies and water resource availability. Water Resour. Manag. 32, 935-947 (2018).

59. Kuik, O. \& Gerlagh, R. Trade liberalization and carbon leakage. Energy J. 24, 97-120 (2003).

60. Ossa, R. Trade wars and trade talks with data. Am. Econ. Rev. 104, 4104-4146 (2014).

61. Hanoch, G. Production and demand models with direct or indirect implicit additivity. Econometrica 43, 395-419 (1975).

62. Muntean, M. et al. Fossil $\mathrm{CO}_{2}$ emissions of all world countries-2018 Report https://doi.org/10.2760/30158, JRC113738 (2018).

63. Sun, J. R. et al. Modulation of the ENSO on winter aerosol pollution in the eastern region of China. J. Geophys. Res. Atmos. 123, 11952-11969 (2018).

64. Revell, L. E. et al. Tropospheric ozone in CCMI models and Gaussian process emulation to understand biases in the SOCOLv3 chemistry-climate model. Atmos. Chem. Phys. 18, 16155-16172 (2018).

65. Fujimori, S., Hasegawa, T., Ito, A., Takahashi, K. \& Masui, T. Gridded emissions and land-use data for 2005-2100 under diverse socioeconomic and climate mitigation scenarios. Sci. Data 5, 180210 (2018).

66. Liu, F. et al. A new global anthropogenic $\mathrm{SO}_{2}$ emission inventory for the last decade: a mosaic of satellite-derived and bottom-up emissions. Atmos. Chem. Phys. 18, 16571-16586 (2018).

67. Lund, M. T. et al. Concentrations and radiative forcing of anthropogenic aerosols from 1750 to 2014 simulated with the Oslo CTM3 and CEDS emission inventory. Geosci. Model Dev. 11, 4909-4931 (2018).

68. Geng, G. et al. Impact of spatial proxies on the representation of bottom-up emission inventories: a satellite-based analysis. Atmos. Chem. Phys. 17, 4131-4145 (2017).

69. Qi, C., Fu, T. M., Hu, J., Qi, Y. \& Lin, Z. Modelling secondary organic aerosols in China. Natl Sci. Rev. 4, 806-809 (2017).

70. Suarez, M. J. et al. The GEOS-5 Data Assimilation System-Documentation of Versions 5.0.1, 5.1.0, and 5.2.0. (2008).

71. Lin, J.-T. \& McElroy, M. B. Impacts of boundary layer mixing on pollutant vertical profiles in the lower troposphere: Implications to satellite remote sensing. Atmos. Environ. 44, 1726-1739 (2010).

72. Wesely, M. L. Parameterization of surface resistances to gaseous dry deposition in regional-scale numerical-models. Atmos. Environ. 23, 1293-1304 (1989). 
73. Wang, Y. H., Jacob, D. J. \& Logan, J. A. Global simulation of tropospheric O3-NOx-hydrocarbon chemistry 1. Model formulation. J. Geophys. Res. Atmos. 103, 10713-10725 (1998).

74. Zhang, L. M., Gong, S. L., Padro, J. \& Barrie, L. A size-segregated particle dry deposition scheme for an atmospheric aerosol module. Atmos. Environ. 35, 549-560 (2001).

75. Liu, H. Y., Jacob, D. J., Bey, I. \& Yantosca, R. M. Constraints from Pb-210 and Be-7 on wet deposition and transport in a global three-dimensional chemical tracer model driven by assimilated meteorological fields. J. Geophys. Res. Atmos. 106, 12109-12128 (2001).

76. Fountoukis, C. \& Nenes, A. ISORROPIA II a computationally efficient thermodynamic equilibrium model for $\mathrm{K}+-\mathrm{Ca} 2+-\mathrm{Mg} 2+-\mathrm{Nh}(4)(+)-\mathrm{Na}$ +-SO42-NO3-Cl-H2O aerosols. Atmos. Chem. Phys. 7, 4639-4659 (2007).

77. Zhang, L. et al. Source attribution of particulate matter pollution over North China with the adjoint method. Environ. Res. Lett. 10, 084011 (2015).

78. Heald, C. L. et al. Atmospheric ammonia and particulate inorganic nitrogen over the United States. Atmos. Chem. Phys. 12, 10295-10312 (2012).

79. Lin, J. et al. Model uncertainties affecting satellite-based inverse modeling of nitrogen oxides emissions and implications for surface ozone simulation. Atmos. Chem. Phys. Discuss. 12, 14269-14327 (2012).

80. Lin, J. et al. Modeling uncertainties for tropospheric nitrogen dioxide columns affecting satellite-based inverse modeling of nitrogen oxides emissions. Atmos. Chem. Phys. 12, 12255-12275 (2012).

81. Ni, R., Lin, J., Yan, Y. \& Lin, W. Foreign and domestic contributions to springtime ozone over China. Atmos. Chem. Phys. 18, 11447-11469 (2018)

82. Pye, H. O. T. \& Seinfeld, J. H. A global perspective on aerosol from lowvolatility organic compounds. Atmos. Chem. Phys. 10, 4377-4401 (2010).

83. Simone, N. W., Stettler, M. E. J. \& Barrett, S. R. H. Rapid estimation of global civil aviation emissions with uncertainty quantification. Transp. Res. Part D Transp. Environ. 25, 33-41 (2013).

84. Wang, C., Corbett, J. J. \& Firestone, J. Improving spatial representation of global ship emissions inventories. Environ. Sci. Technol. 42, 193-199 (2008).

85. Eyring, V., Kohler, H. W., van Aardenne, J. \& Lauer, A. Emissions from international shipping: 1. The last 50 years. J. Geophys. Res. Atmos. 110, D17305 (2005).

86. Eyring, V., Kohler, H. W., Lauer, A. \& Lemper, B. Emissions from international shipping: 2. Impact of future technologies on scenarios until 2050. J. Geophys. Res. Atmos. 110, D17306 (2005).

87. Vestreng, V., Mareckova, K., Kakareka, S., Malchykhina, A. \& Kukharchyk, T., Inventory Review 2007: Emission Data Reported to LRTAP Convention and NEC Directive, MSC-W Technical Report 1/07 (2007).

88. Giglio, L., Randerson, J. T. \& van der Werf, G. R. Analysis of daily, monthly, and annual burned area using the fourth-generation global fire emissions database (GFED4). J. Geophys. Res. 118, 317-328 (2013).

89. Hudman, R. C. et al. Steps towards a mechanistic model of global soil nitric oxide emissions: implementation and space based-constraints. Atmos. Chem. Phys. 12, 7779-7795 (2012).

90. Murray, L. T., Jacob, D. J., Logan, J. A., Hudman, R. C. \& Koshak, W. J. Optimized regional and interannual variability of lightning in a global chemical transport model constrained by LIS/OTD satellite data. J. Geophys. Res. Atmos. 117, D20307 (2012).

91. Ott, L. E. et al. Production of lightning NOx and its vertical distribution calculated from three-dimensional cloud-scale chemical transport model simulations. J. Geophys. Res. Atmos. 115, D04301 (2010).

92. Guenther, A. B. et al. The model of emissions of gases and aerosols from nature version 2.1 (MEGAN2.1): an extended and updated framework for modeling biogenic emissions. Geosci. Model Dev. 5, 1471-1492 (2012).

93. Fairlie, T. D., Jacob, D. J. \& Park, R. J. The impact of transpacific transport of mineral dust in the United States. Atmos. Environ. 41, 1251-1266 (2007).

94. Fairlie, T. D. et al. Impact of mineral dust on nitrate, sulfate, and ozone in transpacific Asian pollution plumes. Atmos. Chem. Phys. 10, 3999-4012 (2010).

95. Zhang, L., Kok, J. F., Henze, D. K., Li, Q. \& Zhao, C. Improving simulations of fine dust surface concentrations over the western United States by optimizing the particle size distribution. Geophys. Res. Lett. 40, 3270-3275 (2013).

96. Jaegle, L., Quinn, P. K., Bates, T. S., Alexander, B. \& Lin, J. T. Global distribution of sea salt aerosols: new constraints from in situ and remote sensing observations. Atmos. Chem. Phys. 11, 3137-3157 (2011).

97. Wang, J. et al. Socioeconomic and atmospheric factors affecting aerosol radiative forcing: production-based versus consumption-based perspective. Atmos. Environ. 200, 197-207 (2019).

98. Heald, C. L. et al. Contrasting the direct radiative effect and direct radiative forcing of aerosols. Atmos. Chem. Phys. 14, 5513-5527 (2014).

99. Gakidou, E. et al. Global, regional, and national comparative risk assessment of 84 behavioural, environmental and occupational, and metabolic risks or clusters of risks, 1990-2016: a systematic analysis for the Global Burden of Disease Study 2016. Lancet 390, 1345-1422 (2017).
100. Chafe, Z. A. et al. Household cooking with solid fuels contributes to ambient $\mathrm{PM}_{2.5}$ air pollution and the burden of disease. Environ. Health Perspect. 122, 1314 (2014).

101. GBD MAPS Working Group. Burden of disease attributable to coal-burning and other major sources of air pollution in China, available at: https://www. healtheffects.org/publication/burden-disease-attributable-coal-burning-andother-air-pollution-sources-china (2016).

102. Jiang, X. et al. Revealing the hidden health costs embodied in Chinese exports. Environ. Sci. Technol. 49, 4381-4388 (2015).

103. Liu, Z. et al. Reduced carbon emission estimates from fossil fuel combustion and cement production in China. Nature 524, 335 (2015).

104. Boden, T. A., Andres, R. J. \& Marland, G. Global, Regional, and National Fossil-Fuel $\mathrm{CO}_{2}$ Emissions. Available at: https://cdiac.ess-dive.lbl.gov/trends/ emis/overview_2014.html (2016).

105. Weum Stjern, C. et al. Global and regional radiative forcing from $20 \%$ reductions in $\mathrm{BC}, \mathrm{OC}$ and $\mathrm{SO}_{4}$ - an HTAP2 multi-model study. Atmos. Chem. Phys. 16, 1-31 (2016).

106. Reddy, M. S. \& Boucher, O. Climate impact of black carbon emitted from energy consumption in the world's regions. Geophys. Res. Lett. 34, L11802 (2007).

\section{Acknowledgements}

This study is supported by the National Natural Science Foundation of China (41775115). K.F. and K.H. acknowledge the funding support from University of Maryland's BSOS Dean's Research Initiative. K.H. acknowledges support from the Czech Science Foundation under the project VEENEX (GA ČR no. 16-17978S). Y.L. acknowledges support from the the National Natural Science Foundation of China (71974186) and National Key Research and Development Program of China (Grant No. 2016YFA0602500).

\section{Author contributions}

J.L. conceived the research. J.L., K.F. and M.D. designed the research. M.D., L.C. and Y.L. performed the research. J.L. and M.D. designed the scenarios. K.F. and Y.L. provided socioeconomic data. Y.Z. provided Chinese emissions data. R.M. and A.v.D. provided satellite-based $\mathrm{PM}_{2.5}$ data. L.C. and M.D. calculated emissions. L.C. and R.N. performed atmospheric simulations. L.C. and J.W. calculated chemical efficiencies. L.C., H.K. and M.D. performed simulations of health impacts. J.L., M.D., L.C. and K.F. led the analysis with inputs from K.H., R.M., H.W., M.L. and Q.L. J.L., M.D. and L.C. led the writing with inputs from Y.L. All authors discussed the results and commented on the manuscript.

\section{Competing interests}

The authors declare no competing interests.

\section{Additional information}

Supplementary Information accompanies this paper at https://doi.org/10.1038/s41467 019-12890-3.

Correspondence and requests for materials should be addressed to J.L., K.F. or Y.L.

Peer review information Nature Communications thanks Manish Shrivastava and the other, anonymous, reviewer(s) for their contribution to the peer review of this work. Peer reviewer reports are available.

Reprints and permission information is available at http://www.nature.com/reprints

Publisher's note Springer Nature remains neutral with regard to jurisdictional claims in published maps and institutional affiliations.

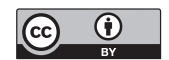

Open Access This article is licensed under a Creative Commons Attribution 4.0 International License, which permits use, sharing, adaptation, distribution and reproduction in any medium or format, as long as you give appropriate credit to the original author(s) and the source, provide a link to the Creative Commons license, and indicate if changes were made. The images or other third party material in this article are included in the article's Creative Commons license, unless indicated otherwise in a credit line to the material. If material is not included in the article's Creative Commons license and your intended use is not permitted by statutory regulation or exceeds the permitted use, you will need to obtain permission directly from the copyright holder. To view a copy of this license, visit http://creativecommons.org/ licenses/by/4.0/.

(c) The Author(s) 2019 